\title{
NEW SPECIES AND RECORDS OF ORCHIDACEAE FROM COSTA RICA. II
}

\author{
Adam P. Karremans ${ }^{1,2,3,6}$, Diego Bogarín ${ }^{1,2,4}$, Melania Fernández ${ }^{1,4}$, \\ Christina M. Smith ${ }^{1} \&$ Mario A. Blanco ${ }^{1,5}$ \\ ${ }^{1}$ Jardín Botánico Lankester, Universidad de Costa Rica, P. O. Box 302-7050 Cartago, Costa Rica \\ ${ }^{2}$ Centro de Investigación en Orquídeas de los Andes "Ángel Andreetta", \\ Universidad Alfredo Pérez Guerrero, Ecuador \\ ${ }^{3}$ NCB Naturalis - NHN Universiteit Leiden, The Netherlands \\ ${ }^{4}$ Herbario UCH, Universidad Autónoma de Chiriquí, David, Panama \\ ${ }^{5}$ Escuela de Biología, Universidad de Costa Rica \\ ${ }^{6}$ Corresponding author: adam.karremans@ucr.ac.cr
}

\begin{abstract}
AвStRact. After the publication of the most recent and comprehensive treatment of the Orchidaceae in the Manual de Plantas de Costa Rica, new species continue being discovered in the country on a regular basis. Novelties in Acianthera, Epidendrum, Lepanthes, Masdevallia, Pleurothallis, and Specklinia are discussed. We present eight new records including the reconsideration of Epidendrum concavilabium (as different from E. circinatum), and the first record of the genus Epistephium (E. ellipticum) for the country. Three new taxa, Epidendrum alieniferum, Epidendrum $\times$ sandiorum (a putative natural hybrid between $E$. oerstedii and $E$. ciliare) and Lepanthes kabebatae are described.

Resumen. Después de la publicación del tratamiento más reciente y completo de Orchidaceae en el Manual de Plantas de Costa Rica, nuevas especies siguen descubriéndose con regularidad en el país. Se discuten novedades en Acianthera, Epidendrum, Lepanthes, Masdevallia, Pleurothallis y Specklinia. Presentamos ocho nuevos registros incluyendo la reconsideración de Epidendrum concavilabium (como distinto de E. circinatum) y el primer registro del género Epistephium (E. ellipticum) en el país. Se describen tres nuevos taxones, Epidendrum alieniferum, Epidendrum $\times$ sandiorum (un híbrido natural putativo entre E. oerstedii y E. ciliare) y Lepanthes kabebatae.
\end{abstract}

Key words: Epidendrum alieniferum, Epidendrum $\times$ sandiorum, Lepanthes kabebatae, Epistephium, Orchidaceae, new records, new species, Costa Rica

This article series is part of an ongoing study of the orchid flora of the country (Bogarín et al. 2008). As mentioned in the first installment, the development of a living collection of native orchids has been an invaluable tool for the inventory efforts that have resulted in a rapid increase in the knowledge of the Costa Rican orchid flora. This approach has proven to be much more effective than studying only herbarium material.

Since the latest treatment of the Orchidaceae in the "Manual de Plantas de Costa Rica" (referred to as the "Manual" throughout this paper; Dressler 2003), many species were reported or described from Costa Rica. A few hundred novelties (both nomenclatural and taxonomic) in some 50 genera were published since the Manual was printed. Most are actually just new names for known species and therefore do not account for a net increase in the number of species, however about half (ca. 130) are true novelties and reflect an increase in Costa Rican orchid diversity. A summary of all articles that have appeared since the publication of the Manual and include species descriptions or nomenclatural changes affecting Costa Rican orchid taxa is presented in Table 1.

Novelties were described from remote areas and from relatively well-botanized sites, and frequently citing few herbarium specimens. For example, only two plants of Acianthera cabiriae Pupulin, G.A.Rojas \& J.D.Zuñiga were ever found at the well botanized site of CATIE, Turrialba (Pupulin et al. 2007). On the other hand, several plants of Pleurothallis adventurae Karremans \& Bogarín were found growing 
TABLE 1. List of orchid genera cited in the Manual de Plantas de Costa Rica for which species have been added and/or removed. The reference is given to every nomenclatural modification. Abbreviations $\mathrm{NC}=$ Name Change; $\mathrm{NR}=\mathrm{New}$ Record; NS= New Species; $\mathrm{Y}=$ Increase in net species number; $\mathrm{N}=$ No increase in net species number.

\begin{tabular}{|c|c|c|}
\hline Genus & Reference & Category \\
\hline Acianthera & Pupulin, Rojas \& Zúñiga 2007; Bogarín et al. 2008 & NS-Y \\
\hline Anathallis & Luer 2006 & NR-Y \\
\hline Aspidogyne & Ormerod 2007; Ormerod 2009 & NS-Y \\
\hline Barbosella & Bogarín et al. 2008 & NR-Y \\
\hline Brassia & Christenson 2003b; Pupulin \& Bogarín 2005a & NC/NS-Y \\
\hline Campylocentrum & Pupulin \& Bogarín 2010b & NC/NS/NR-Y \\
\hline Chondroscaphe & Pupulin 2005a; Pupulin et al. 2009. & NC/NS-N \\
\hline Cischweinfia & Christenson 2003a; Dressler \& Dalström 2004 & $\mathrm{NC/NS}-\mathrm{N}$ \\
\hline Coccineorchis & Rutkowski et al. 2004 & NS-Y \\
\hline Coryanthes & Gerlach \& Dressler 2003; Gerlach \& Romero-González 2008 & NC/NS-N \\
\hline Crossoglossa & Pupulin \& Karremans 2010a & NS-Y \\
\hline Cyrtopodium & Romero-González \& Carnevali 1999 & NC-N \\
\hline Dichaea & $\begin{array}{l}\text { Pupulin 2005a; Pupulin 2005b; Pupulin 2005c; Dressler, Pupulin \& Folsom } \\
\text { 2006; Pupulin } 2007\end{array}$ & $\mathrm{NC} / \mathrm{NS}-\mathrm{N}$ \\
\hline Dracontia & Karremans in press; Karremans \& Smith in press & NC/NS-N \\
\hline Dryadella & Luer 2005 & NC-N \\
\hline Brenesia & Bogarín et al. 2008 & NR-Y \\
\hline Elleanthus & Dressler \& Bogarín 2007; Dressler \& Bogarín 2010 & NS-Y \\
\hline Encyclia & Pupulin 2006 & NS-Y \\
\hline Epidendrum & $\begin{array}{l}\text { Bogarín et al. 2008; Hágsater 2003; 2004; 2006; 2007; 2008; 2009; } \\
\text { Karremans \& Hágsater 2010; Pupulin \& Karremans 2010b }\end{array}$ & $\mathrm{NC/NS/NR-Y}$ \\
\hline Galeandra & Pupulin 2005a & NS-Y \\
\hline Gongora & Jenny 2007 & NS-Y \\
\hline Habenaria & Batista et al. 2011 & - \\
\hline Kefersteinia & Pupulin \& Merino 2008 & NS-Y \\
\hline Kraenzlinella & Luer 2011 & NS-Y \\
\hline Kreodanthus & Ormerod 2008 & NS-Y \\
\hline Lepanthes & $\begin{array}{l}\text { Blanco 2003; Bogarín \& Fernández 2010; Bogarín \& Pupulin 2010a; } \\
\text { 2011; Pupulin 2003a; Pupulin \& Bogarín 2004; 2010a; 2011a; 2011b; } \\
\text { 2012; Pupulin, Bogarín \& Jiménez 2009; Pupulin, Medina \& Bogarín } \\
\text { 2010; Pupulin, Bogarín \& Smith } 2010\end{array}$ & NS/NR-Y \\
\hline Lockhartia & Bogarín et al. 2008 & NR-Y \\
\hline Lycaste & Bogarín 2007; Oakeley 2008 & NC/NS-Y \\
\hline Masdevallia & Smith \& Pupulin in prep. & NS-Y \\
\hline Maxillaria & Pupulin 2003b; Bogarín et al. 2008 & NS/NR-Y \\
\hline Microchilus & Ormerod 2004; 2005; 2007 & NC/NS-Y \\
\hline Mormolyca & Bogarín \& Pupulin 2010 & NS-Y \\
\hline Myoxanthus & Bogarín et al. 2008; Pupulin, Bogarín \& Fernández 2010b & NS/NR-Y \\
\hline Octomeria & Luer 2010 & NR-Y \\
\hline Ornithidium & Blanco et al. 2008a & NR-Y \\
\hline Ornithocephalus & Pupulin 2002a & NS-Y \\
\hline Palmorchis & Bainbridge \& Aguilar 2008 & NR-Y \\
\hline Panmorphia & Luer 2006 & NR-Y \\
\hline Phragmipedium & Christenson 2006a; Pupulin \& Dressler 2011 & NC-N \\
\hline
\end{tabular}


TABle 1. Continues.

\begin{tabular}{|c|c|c|}
\hline Genus & Reference & Category \\
\hline Platystele & Bogarín \& Karremans 2010 & NS-Y \\
\hline Platythelys & Ormerod 2007 & NS-Y \\
\hline Pleurothallis & $\begin{array}{l}\text { Karremans \& Bogarín 2011; Karremans \& Muñoz 2011; Luer 2002; } \\
\text { Pupulin \& Zúñiga 2007; Pupulin, Bogarín \& Fernández 2010a; }\end{array}$ & NS-Y \\
\hline Polycycnis & Gerlach 2004 & NC/NS-N \\
\hline Polystachya & Mytnik-Ejsmont 2011 & NR-Y \\
\hline Prosthechea & Pupulin 2004 & NS-Y \\
\hline Restrepiella & Pupulin \& Bogarín 2007 & NS-Y \\
\hline Scaphyglottis & Dressler 2004a; Bogarín et al. 2008 & NS/NR-Y \\
\hline Scelochilus & Pupulin \& Bogarín 2005b & $\mathrm{NC}-\mathrm{N}$ \\
\hline Sigmatostalix & Pupulin \& Rojas 2006 & NS-Y \\
\hline Sobralia & $\begin{array}{l}\text { Bogarín et al. 2008; Dressler 2002; 2007; Dressler \& Pupulin 2008; } \\
\text { Dressler \& Bogarín 2010; } 2011\end{array}$ & NC/NS/NR-Y \\
\hline Specklinia & Luer 2006 & NR-Y \\
\hline Stanhopea & Gerlach \& Beeche 2004 & $\mathrm{NC}-\mathrm{N}$ \\
\hline Stenorrhynchos & Christenson 2005 & NC/NS-Y \\
\hline Stellilabium & Pupulin 2003b; Pupulin 2003c; Pupulin \& Blanco 2002 & NS-Y \\
\hline Trichopilia & Dressler \& Pupulin 2005; 2006; Dressler \& Bogarín 2009 & $\mathrm{NC} / \mathrm{NS}-\mathrm{Y}$ \\
\hline Trichosalpinx & Fernández 2011; Fernández \& Bogarín 2012 & NS-Y \\
\hline Trigonidium & Christenson 2002 & $\mathrm{NC}-\mathrm{N}$ \\
\hline Vanilla & Soto Arenas \& Dressler 2010 & NC/NS-Y \\
\hline Warmingia & Bogarín et al. 2008 & $\mathrm{NC}-\mathrm{N}$ \\
\hline
\end{tabular}

on a tree just outside of a shelter cabin close to the Panamanian border in the Cordillera de Talamanca, in a less intensely explored region. No material of either species was found in any of the main Costa Rican herbaria (CR, INB, JBL, USJ), which indicates that some species might be both conspicuous and relatively frequent but grow in relatively unexplored regions, while others might occur in more frequented sites but be scarce and/or inconspicuous.

In addition to novelties, important nomenclatural changes were proposed for many orchid taxa present in Costa Rica in the last decade. Proposals to split Masdevallia Ruiz \& Pav., Maxillaria Ruiz \& Pav., Pleurothallis R.Br. and Prosthechea Knowles \& Westc. are the ones that account for most of the new combinations. A summary of these proposed generic segregates is presented in Table 2. On the other hand proposals to reduce several genera to the synonymy of others were also published; most notable are the inclusion of Oerstedella Rchb.f. in Epidendrum L., Sigmatostalix Rchb.f. in Oncidium Sw. and Stellilabium Schltr. in Telipogon Kunth. A summary of those proposed generic "lumpings" is presented in Table 3.

All in all, close to half of the orchid genera accepted in the Manual have either gained and/or lost species due to generic transfers, species descriptions and/or reduction to synonymy. Given the steady discovery of novelties and phylogenetic reconstructions based on DNA, any published orchid inventory for Costa Rica becomes outdated in a matter of a few years. Bogarín (2011) listed ca. 200 new names published for the Costa Rican orchid flora between 2001 and 2008. If that tendency is maintained, which is a likely scenario, in a couple of decades the number of known orchid species in the country will exceed 2000.

As part of routine botanical exploration, documentation, and identification of orchids at Lankester Botanical Garden, more novelties continue to accumulate. On that note, we reveal the following new records from Costa Rica. Most of these were discovered from the direct study of live material; in all cases additional specimens were sought in the main Costa Rican herbaria (CR, INB, JBL, USJ) and, if found, are cited in the corresponding accounts presented below. 
TABLE 2. List of orchid genera cited in the Manual de Plantas de Costa Rica which have been split by recent authors. Segregate genera are given for each generic name accepted in the Manual.

\begin{tabular}{|c|c|c|}
\hline Genus & Segregate Genera & Reference \\
\hline Cattleya & Guarianthe Dressler \& W.E.Higgins & Dressler \& Higgins 2003 \\
\hline Chondrorhyncha & $\begin{array}{l}\text { Benzingia Dodson } \\
\text { Daiotyla Dressler } \\
\text { Stenotyla Dressler }\end{array}$ & $\begin{array}{l}\text { Romero-González \& Dodson } 2010 \\
\text { Whitten et al. } 2005 \\
\text { Whitten et al. } 2005\end{array}$ \\
\hline Elleanthus & $\begin{array}{l}\text { Adeneleuterophora Barb. Rodr. } \\
\text { Epylina Schltr. } \\
\text { Evelyna Poepp. \& Endl. }\end{array}$ & $\begin{array}{l}\text { Dudek \& Szlachetko } 2010 \\
\text { Dudek \& Szlachetko } 2010 \\
\text { Dudek \& Szlachetko } 2010\end{array}$ \\
\hline Eltroplectris & Callistanthos Szlach. & Szlachetko \& Rutkowski 2008 \\
\hline Epidendrum & Coilostylis Raf. & Whitner \& Harding 2004 \\
\hline Erythrodes & $\begin{array}{l}\text { Aspidogyne Garay } \\
\text { Kreodanthus Garay } \\
\text { Microchilus C.Presl } \\
\text { Platythelys Garay }\end{array}$ & $\begin{array}{l}\text { Ormerod 2007; Ormerod } 2009 \\
\text { Ormerod } 2008 \\
\text { Ormerod } 2002 \\
\text { Ormerod } 2007\end{array}$ \\
\hline Galeottiella & Funkiella Schltr. & Solano et al. 2011 \\
\hline Habenaria & $\begin{array}{l}\text { Bertauxia Szlach. } \\
\text { Habenella Small } \\
\text { Platantheroides Szlach. }\end{array}$ & $\begin{array}{l}\text { Szlachetko 2004a } \\
\text { Szlachetko \& Kras } 2006 \\
\text { Szlachetko 2004b }\end{array}$ \\
\hline Kefersteinia & Senghasia Szlachetko & Szlachetko 2003; Szlachetko, Kulak \& Romowicz 2006. \\
\hline Lycaste & Selbyana Archila & Archila 2010 \\
\hline Malaxis & Microstylis (Nutt.) Eaton & Szlachetko \& Margońska 2006 \\
\hline Masdevallia & $\begin{array}{l}\text { Acinopetala Luer } \\
\text { Alaticaulia Luer } \\
\text { Buccella Luer } \\
\text { Diodonopsis Pridgeon \& M.W.Chase } \\
\text { Fissia (Luer) Luer } \\
\text { Reichantha Luer } \\
\text { Spilotantha Luer } \\
\text { Zahleria (Luer) }\end{array}$ & $\begin{array}{l}\text { Luer } 2006 \\
\text { Luer } 2006 \\
\text { Luer } 2006 \\
\text { Pridgeon \& Chase } 2001 \\
\text { Luer } 2006 \\
\text { Luer } 2006 \\
\text { Luer } 2006 \\
\text { Luer } 2006\end{array}$ \\
\hline Maxillaria & $\begin{array}{l}\text { Adamanthus Szlach. } \\
\text { Camaridium Lindl. } \\
\text { Christensonella Szlach., Mytnik, Górniak \& Śmiszek } \\
\text { Heterotaxis Lindl. } \\
\text { Inti M.A.Blanco } \\
\text { Mapinguari Carnevali \& R.B.Singer } \\
\text { Maxillariella M.A.Blanco \& Carnevali } \\
\text { Mormolyca Fenzl } \\
\text { Nitidobulbon Ojeda, Carnevali \& G.A.Romero } \\
\text { Ornithidium Salisb. ex R. Br. } \\
\text { Rhetinantha M.A.Blanco } \\
\text { Sauvetrea Szlach. }\end{array}$ & $\begin{array}{l}\text { Szlachetko \& Śmiszek } 2006 \\
\text { Blanco et al. } 2007 \\
\text { Szlachetko, Mytnik, Górniak \& Śmiszek } 2006 \\
\text { Ojeda, Carnevali \& Romero } 2005 \\
\text { Blanco et al. } 2007 \\
\text { Blanco et al. } 2007 \\
\text { Blanco et al. } 2007 \\
\text { Blanco et al. } 2007 \\
\text { Ojeda, Carnevali \& Romero } 2009 \\
\text { Blanco et al. } 2007 \\
\text { Blanco et al. } 2007 \\
\text { Blanco et al. } 2007\end{array}$ \\
\hline Oncidium & $\begin{array}{l}\text { Brevilongium Christenson } \\
\text { Chelyorchis Dressler \& N.H.Williams } \\
\text { Heteranthocidium Szlach., Mytnik \& Romowicz } \\
\text { Otoglossum (Schltr.) Garay \& Dunst. }\end{array}$ & $\begin{array}{l}\text { Christenson 2006b } \\
\text { Dressler \& Williams 2000; Carnevali et al. } 2009 \\
\text { Szlachetko, Mytnik \& Romowicz } 2006 \\
\text { Williams et al. } 2001\end{array}$ \\
\hline
\end{tabular}


TABLE 2. Continues.

\begin{tabular}{|c|c|c|}
\hline Genus & Segregate Genera & Reference \\
\hline Oncidium & $\begin{array}{l}\text { Rossioglossum (Schltr.) Garay \& G.C.Kenn. } \\
\text { Stacyella Szlach. } \\
\text { Trichocentrum Poepp. \& Endl. } \\
\text { Vitekorchis Romowicz \& Szlach. }\end{array}$ & $\begin{array}{l}\text { Chase et al. } 2008 \\
\text { Szachetko } 2006 \\
\text { Williams et al. } 2001 \\
\text { Romowicz \& Szachetko } 2006 .\end{array}$ \\
\hline Pleurothallis & $\begin{array}{l}\text { Aberrantia Luer } \\
\text { Acronia C.Presl } \\
\text { Acianthera Scheidw. } \\
\text { Anathallis Barb.Rod. } \\
\text { Ancipitia (Luer) Luer } \\
\text { Apoda-prorepentia (Luer) Luer } \\
\text { Crocodeilanthe Rchb.f. \& Warsz. } \\
\text { Didactylus Luer } \\
\text { Dracontia (Luer) Luer } \\
\text { Echinella Pridgeon \& M.W.Chase } \\
\text { Echinosepala Pridgeon \& M.W.Chase } \\
\text { Effusiella Luer } \\
\text { Elongatia (Luer) Luer } \\
\text { Empusella (Luer) Luer } \\
\text { Gerardoa Luer } \\
\text { Kraenzlinella Kuntze } \\
\text { Loddigesia Luer } \\
\text { Lomax Luer } \\
\text { Muscarella Luer } \\
\text { Niphantha Luer } \\
\text { Pabstiella Brieger \& Senghas } \\
\text { Panmorphia Luer } \\
\text { Phloeophila Hoehne \& Schltr. } \\
\text { Rhynchopera Klotzsch } \\
\text { Ronaldella Luer } \\
\text { Sarcinula Luer } \\
\text { Specklinia Lindl. } \\
\text { Stelis Sw. } \\
\text { Tribulago Luer } \\
\text { Sylphia Luer } \\
\text { Unciferia (Luer) Luer } \\
\text { Unguella (Luer) Luer } \\
\text { Zosterophyllanthos Szlach. \& Marg. }\end{array}$ & $\begin{array}{l}\text { Luer } 2005 \\
\text { Luer } 2005 \\
\text { Pridgeon \& Chase 2001; Solano et al. } 2011 \\
\text { Pridgeon \& Chase 2001; Hágsater \& Soto } 2003 \\
\text { Luer } 2004 \\
\text { Luer } 2004 \\
\text { Luer } 2004 \\
\text { Luer } 2005 \\
\text { Luer } 2004 \\
\text { Pridgeon \& Chase 2001 } \\
\text { Pridgeon \& Chase 2002 } \\
\text { Luer } 2007 \\
\text { Luer } 2004 \\
\text { Luer } 2004 \\
\text { Luer } 2006 \\
\text { Luer } 2004 \text {; Hágsater \& Soto } 2003 \\
\text { Luer } 2006 \\
\text { Luer } 2006 \\
\text { Luer } 2006 \\
\text { Luer } 2010 \\
\text { Luer } 2007 \\
\text { Luer } 2006 \\
\text { Pridgeon \& Chase } 2001 ; \text { Luer } 2006 \\
\text { Szlachetko \& Margońska } 2001 \\
\text { Luer } 2006 \\
\text { Luer } 2006 \\
\text { Pridgeon \& Chase 2001; Hágsater \& Soto } 2003 \\
\text { Pridgeon \& Chase } 2001 \\
\text { Luer } 2004 ; \text { Luer } 2006 \\
\text { Luer } 2006 \\
\text { Luer } 2004 \\
\text { Luer } 2005 \\
\text { Szlachetko \& Margońska 2001; Szlachetko \& Kulak } 2006\end{array}$ \\
\hline Prosthechea & $\begin{array}{l}\text { Anacheilium Rchb.f. ex Hoffmanns } \\
\text { Hormidium (Lindl.) Heynh. } \\
\text { Panarica Withner \& P. A.Harding } \\
\text { Pollardia Withner \& P. A.Harding } \\
\text { Pseudencyclia Chiron \& V.P.Castro }\end{array}$ & $\begin{array}{l}\text { Whitner \& Harding } 2004 \\
\text { Whitner \& Harding } 2004 \\
\text { Whitner \& Harding } 2004 \\
\text { Whitner \& Harding } 2004 \\
\text { Chiron \& Castro-Neto } 2003\end{array}$ \\
\hline Schiedeella & Funkiella Schltr. & Solano et al. 2011 \\
\hline Stanhopea & Stanhopeastrum Rchb.f & Szlachetko 2007 \\
\hline Trichosalpinx & Tubella (Luer) Archila & Archila 2000 \\
\hline
\end{tabular}


TABLE 3. List of orchid genera cited in the Manual de Plantas de Costa Rica which have been lumped into other genera by recent authors. The absorbing genus is given for each generic name accepted in the Manual.

\begin{tabular}{l|l|l} 
Genus & Reduced under & Reference \\
\hline Acostaea & Specklinia & Pridgeon \& Chase 2001 \\
\hline Ada & Brassia & Chase \& Whitten 2011 \\
\hline Amparoa & Rhynchostele & Hágsater \& Soto 2003 \\
\hline Chelyorchis & Rossioglossum & Chase et al. 2008 \\
\hline Goniochilus & Leochilus & Chase et al. 2008 \\
\hline Hybochilus & Leochilus & Chase et al. 2008 \\
\hline Leucohyle & Trichopilia & Dressler 2004b \\
\hline Mesospinidium & Brassia & Chase \& Whitten 2011 \\
\hline Oerstedella & Epidendrum & Hágsater \& Soto 2005a \\
\hline Osmoglossum & Cuitlauzina & Dressler \& Williams 2003 \\
\hline Pachyphyllum & Fernandezia & Chase \& Whitten 2011 \\
\hline Pleurothallis & Stelis & Pridgeon \& Chase 2001; Hágsater \& Soto 2003 \\
\hline Psygmorchis & Erycina & Williams et al. 2001 \\
\hline Restrepiopsis & Pleurothallopsis & Pridgeon \& Chase 2001 \\
\hline Salpistele & Stelis & Pridgeon \& Chase 2001 \\
\hline Scelochilus & Comparettia & Chase et al. 2008 \\
\hline Sigmatostalix & Oncidium & Chase et al. 2008 \\
\hline Stellilabium & Telipogon & Williams et al. 2005 \\
\hline Ticoglossum & Rossioglossum & Chase et al. 2008 \\
\hline
\end{tabular}

1.Acianthera oscitans (Ames) Pridgeon \& M.W.Chase, Lindleyana 16: 245. 2001; Pleurothallis oscitans Ames, Bot. Mus. Leafl. 2(2): 25-27. 1934; Didactylus oscitans (Ames) Luer, Monogr. Syst. Bot. Missouri Bot. Gard. 95: 257. 2004. TYPE: Honduras, Cortés, Santa Cruz de Yojoa. Epiphyte in open mountain forest at 2000 feet altitude. Flowers dark purple. August 26, 1933. J.B. Edwards 515 (holotype, AMES).

Distribution: Honduras, Costa Rica and Panama.

Eтymology: Not indicated in the protologue. Luer (2004) suggested the name probably refers to the typically drooping inflorescence.

Habitat in Costa Rica: This species has been found growing epiphytically at around $700 \mathrm{~m}$ in the transition from very humid tropical lowland forest to premontane forest of the Braulio Carrillo National Park, on the Atlantic watershed of the Central Volcanic chain.

Phenology: Flowering around August under cultivation.

Costa Rican material studied: San José: Vázquez de Coronado, Jesús, Parque Nacional Braulio Carrillo,
Sendero La Botella, 1009'33.9”N 83॰57'14.8”W, $702 \mathrm{~m}$, bosque muy húmedo tropical transición a premontano, epífitas en bosque secundario y primario, colectado 2 junio 2010, floreció en cultivo en agosto 2011, D. Bogarín 7621, M. Fernández \& A.P. Karremans (JBL-Spirit!; figures 1, 14A). Heredia: Horquetas, Colonia Cubujuquí, hacia las orillas del Braulio Carrillo. $10^{\circ} 19^{\prime} \mathrm{N} 84^{\circ} 00^{\prime} \mathrm{W}$, ca. $300 \mathrm{~m}$. A orillas de un riachuelo. 25 de febrero 2012, A.P. Karremans 5175 (CR!).

Acianthera oscitans is most similar to Acianthera butcheri (L.O.Williams) Pridgeon \& M.W.Chase, from which it can be distinguished by the ellipticovate leaves, the flower with the tip of the dorsal sepal connate to the synsepal (reminiscent of the flowers of some Zootrophion spp.), the synsepal with revolute margins and the lip narrowly ovate and ciliate. Luer (2005) placed A. oscitans, A. butcheri (also known from Costa Rica) and the Ecuadorian Pleurothallis paradoxa Luer \& Dalström and Pleurothallis thysana Luer \& J.Portilla together in the genus Didactylus, distinguished from Acianthera by the rostellum with two narrow, curved, lateral lobes. 


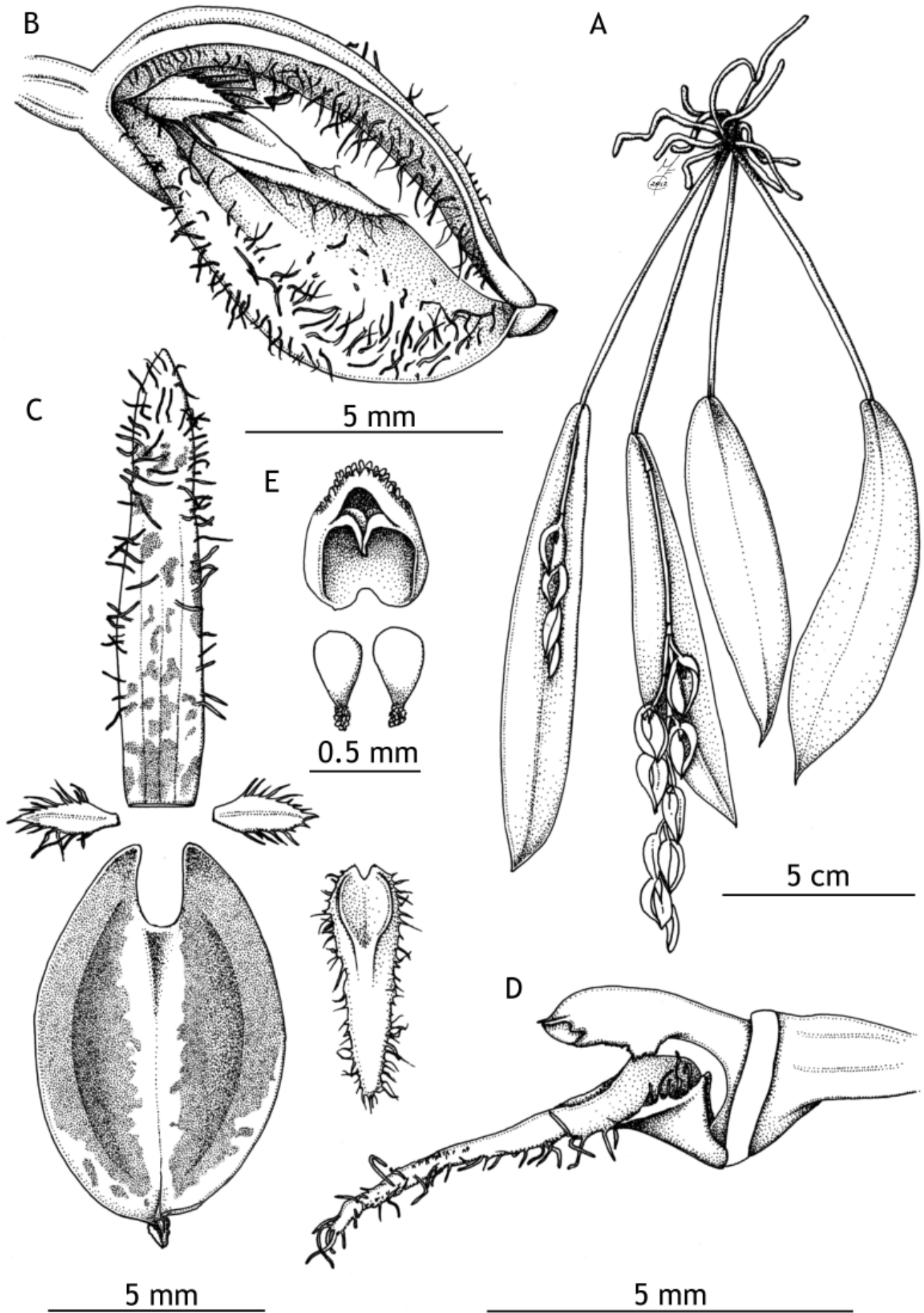

Figure 1. Acianthera oscitans (Ames) Pridgeon \& M.W.Chase. A - Habit; B - Flower; C - Dissected perianth; D - Column and lip, lateral view; E - Anther and pollinaria. Drawn by M. Fernández from D. Bogarín 7621 (JBLSpirit). 


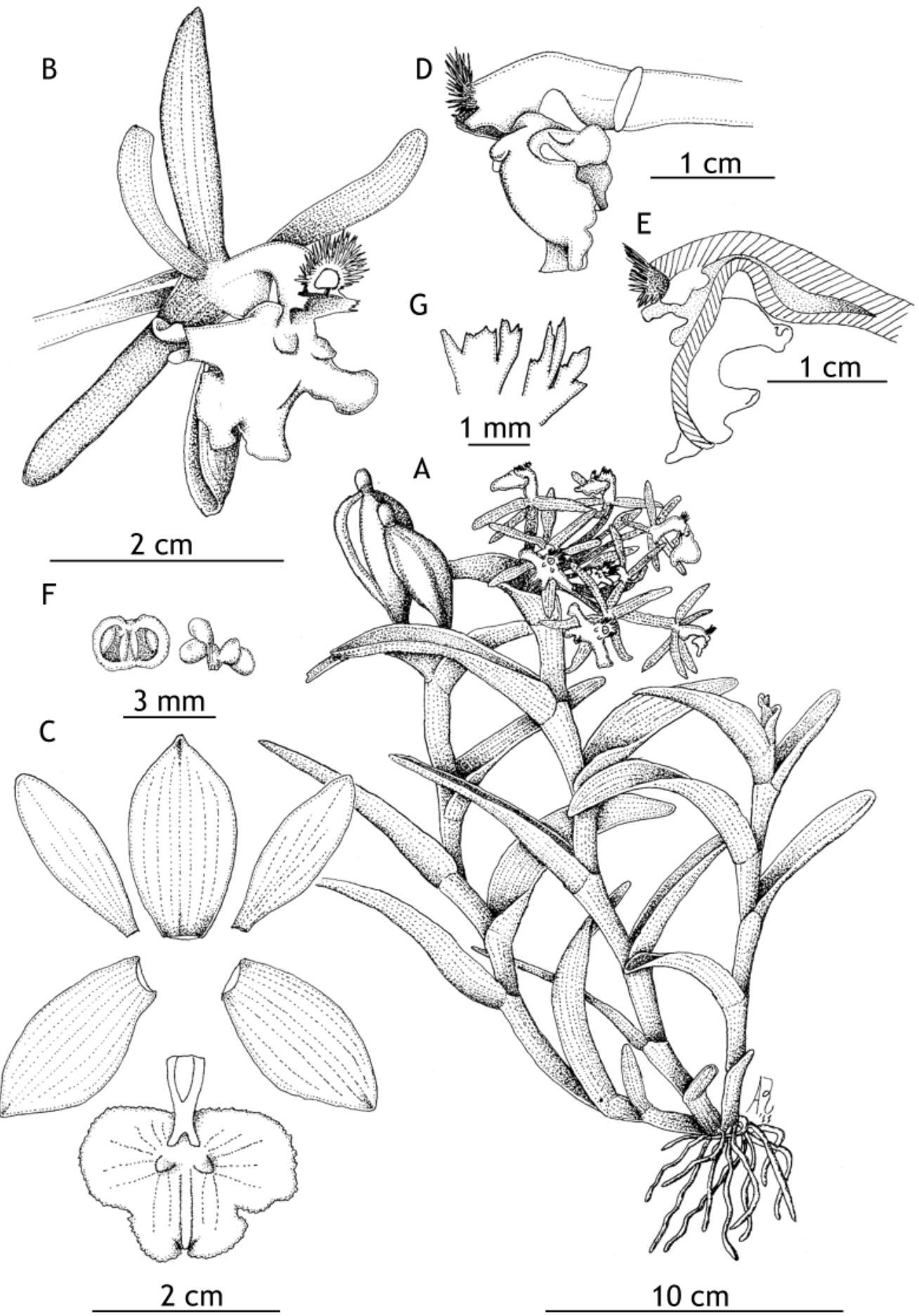

FiguRE 2. Epidendrum alieniferum Karremans \& Bogarín. A - Habit. B - Flower. C - Dissected perianth. D — Column and lip, lateral view. E - Column and lip, longitudinal section. F - Pollinarium and anther cap. G - Clinandrium lacerations. Drawn by A.P. Karremans, based on the plant used as type (JBL-Spirit). 
2. Epidendrum alieniferum Karremans \& Bogarín, sp. nov.

Type: Costa Rica. Puntarenas: Coto Brus, Sabalito, Mellizas, entre Finca Gemelas y Finca Mellizas, 8 53’32.53” N 8246’17.83” W, $1412 \mathrm{~m}$, bosque muy húmedo premontano, epífita en árboles en potreros y cafetales "florentem invenimus ad agros Coffeae et in pascuis supra Acnistus prope opidum Mellizas", 18 abril 2011, A. P. Karremans 3970, D. Bogarín \& D. Jiménez (holotype, CR!; isotype, JBL-Spirit!; figures 2, 14B).

Species Epidendro lagenocolumnae Hágsater et Sánchez similis, sed floribus majoribus, columnae basi inflatiore, labello crenulato, clinandrio prominenti profunde lacerato lacerationibus radialibus differt.

Epiphytic, caespitose, erect herb, up to $25 \mathrm{~cm}$ tall. Roots basal, fleshy, filiform. Stems terete, somewhat flattened. Leaves 4-8(9), distributed along the stem, especially close to the apex; sheath tubular, rugose; blades elliptic, obtuse, variable in size, the largest up to 6-10 $\times 2.5-3.2 \mathrm{~cm}$. Inflorescence apical, subumbellate; peduncle reduced. Floral bracts acute, 0.5 cm long. Flowers 4-10, greenish. Ovary pedicellate, terete, smooth. Sepals partly spreading, slightly bent backwards, elliptic, obtuse, 7-veined, margin entire, revolute; dorsal sepal 21-22 × 11-12 mm, lateral sepals oblique, 20-22 × 10-11 mm. Petals spreading, porrect, narrowly-elliptic, obtuse, 5-veined, margin entire, revolute, 20-22 × 6-7 mm. Lip trilobed, basal lobes widely ovate-elliptic, mid-lobe sub-quadrate, emarginate, bicallose, with a low central keel, margins crenulate, folded, appearing cross-like in natural position, $22 \times 22-23 \mathrm{~mm}$. Column strongly arching downwards, thickened basally, sub-terete, $13-15 \mathrm{~mm}$ long, with a pair of arm-like wings; clinandriumhood erect, prominent, margins radially lacerate; rostellum near the apex of the column, slit. Anther cap transverse-elliptic, 4-celled, $3 \mathrm{~mm}$ wide. Pollinia 4, obovoid, laterally compressed. Nectary short, barely penetrating the ovary, smooth. Fruit ellipsoid.

Paratypes: Costa Rica. Same locality and date as the holotype, A. P. Karremans 3971, D. Bogarín \& D. Jiménez (JBL-Spirit!). Puntarenas: Coto Brus. Z.P. Las Tablas. Cuenca Térraba-Sierpe. Estación Progreso, S. Fila Palmital, colectando en bosque primario. Epífita, flores crema. $8^{\circ} 55^{\prime} 00.3640^{\prime \prime} \mathrm{N}-82^{\circ} 46^{\prime} 58.3450^{\prime \prime} \mathrm{W}$. 1440 m, 24 mayo 1999, M. Alfaro 183 (CR!, INB!).

Distribution: Known only from Costa Rica, but most probably occurring also in Panama, as the three known specimens were collected close to the Panamanian border.

Eтyмоlogy: From the Latin alienus, alien, stranger, and fero, bearing. In allusion to the frontal view of the folded lip and column apex in natural position, reminiscent of little green human-like figures; bearing strange beings.

Habitat in Costa Rica: Epiphytic in primary and secondary humid premontane forest, at around $1400-1450$ m elevation. It is known only from the southernmost portion of the Pacific slope of the Cordillera de Talamanca.

Phenology: Flowering recorded in April in the field and in May under cultivation.

Epidendrum alieniferum is most similar to $E$. lagenocolumna Hágsater \& Sánchez (1993), but it can be distinguished by the larger flowers (sepals 2022 vs. 13-18 mm long and 10-12 vs. 4-6 mm wide, respectively), the shape of petals (elliptic vs. linear), the lip crenulate (vs. entire), the base of the column more inflated (twice the column width vs. being less than twice the width), and the prominent clinandrium, with radial lacerations (vs. obsolete). It also grows at lower elevations than E. lagenocolumna, which in Costa Rica is normally found above $1800 \mathrm{~m}$, and is only known from the southern part of the Pacific watershed of the Talamanca range, whereas the former is known throughout the country. The variable $E$. firmum Rchb.f. is also similar; however it is smaller in both plant and flower size, has linear petals, a column that is not thickened at the base and does not have such a prominent, erect, lacerate clinandrium (Sánchez \& Hágsater 2007).

3. Epidendrum concavilabium C.Schweinf., Bot. Mus. Leafl. 4: 118. 1937. TyPe: Costa Rica. Colinas de San Pedro de San Ramón, Nov. 1927, A.M. Brenes (119) 1660 (holotype, AMES; photo of type at AMES!).

\section{Distribution: Costa Rica.}

LANKESTERIANA 12(1), April 2012. (C) Universidad de Costa Rica, 2012. 

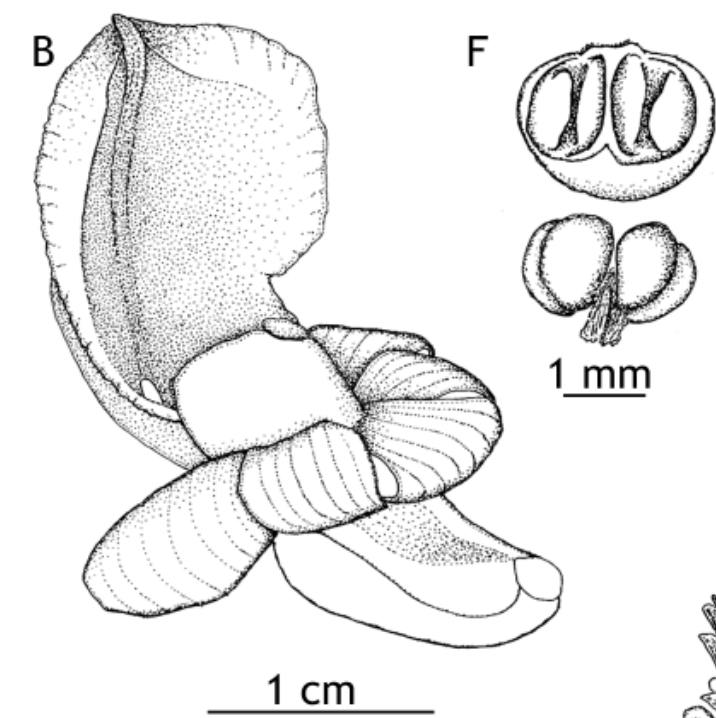

$1 \mathrm{~mm}$

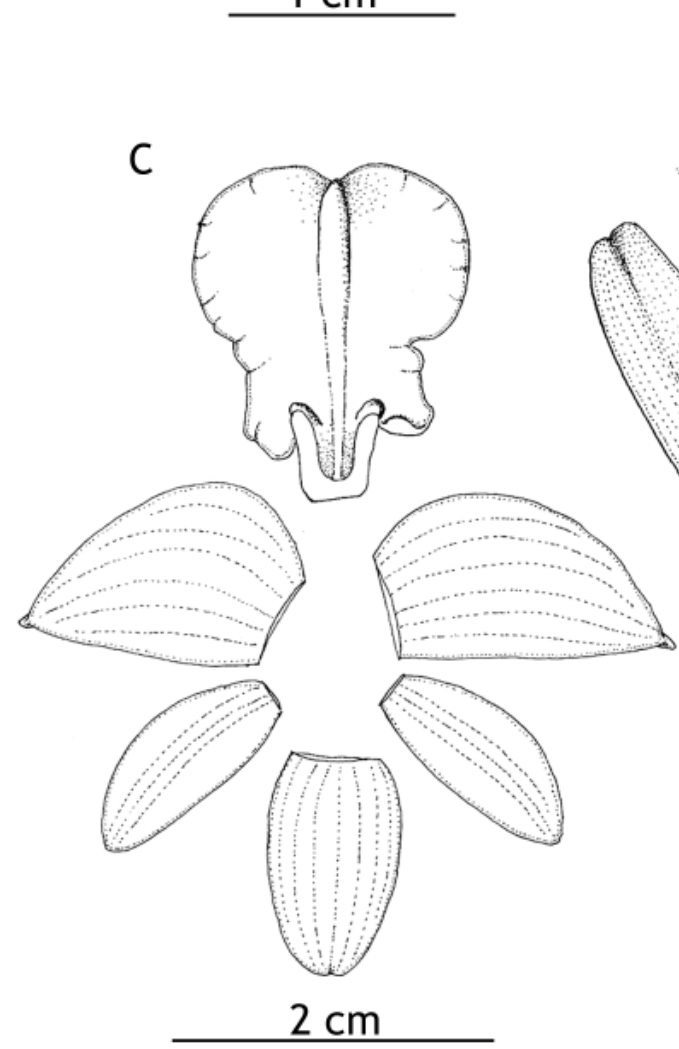

A

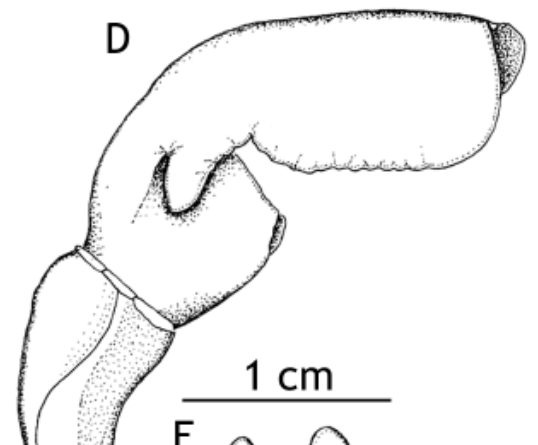

A

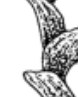

$\mathrm{E}$




B
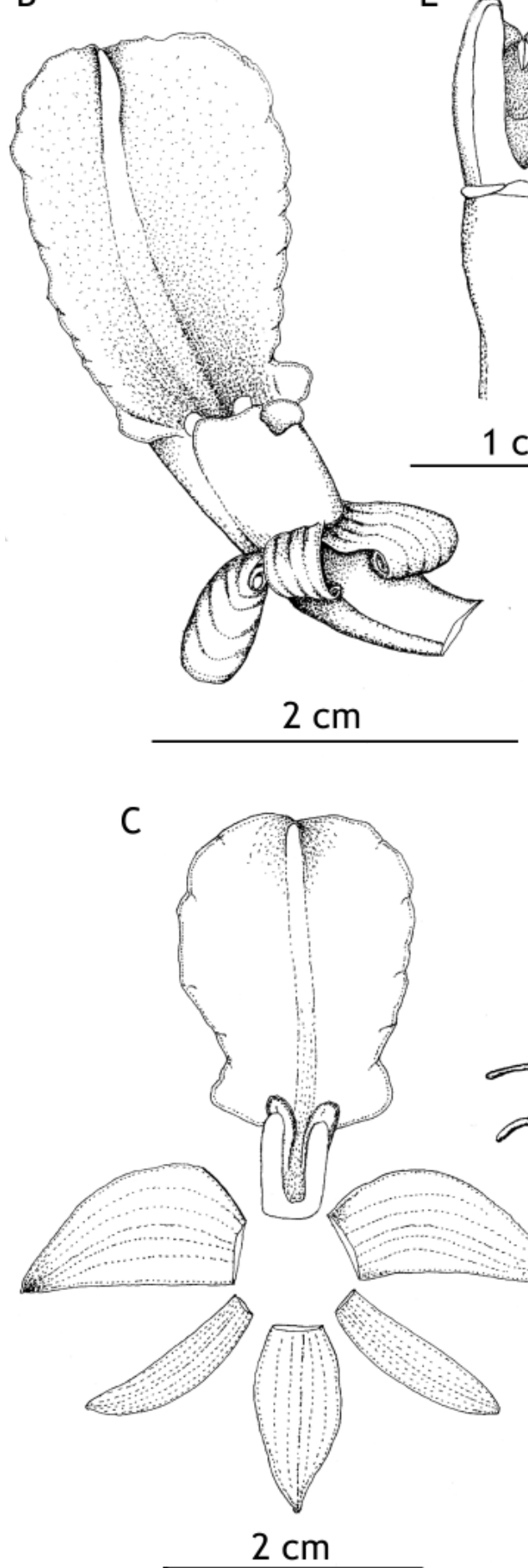

A
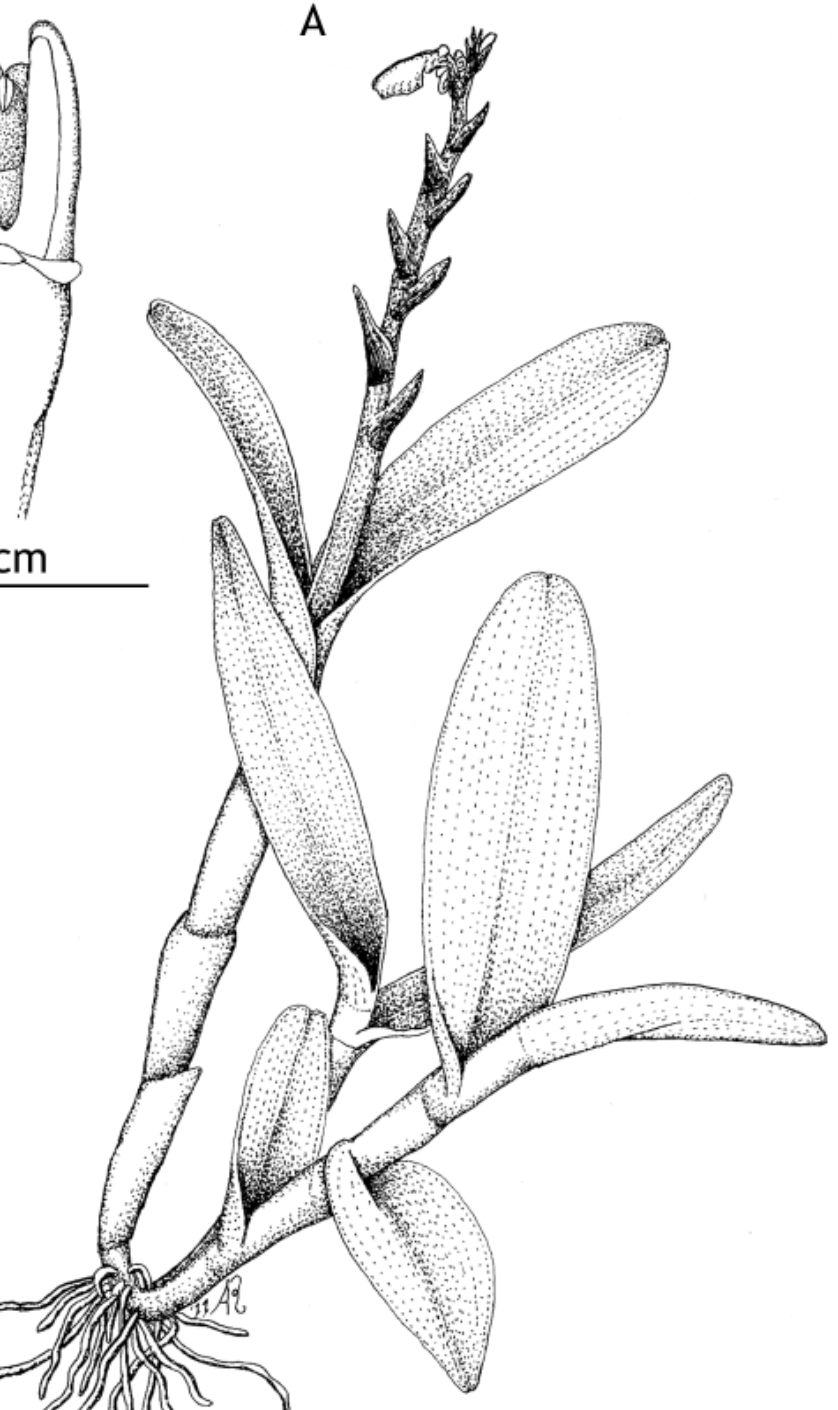

Figure 4. Epidendrum circinatum Ames. A - Habit. B — Flower. C — Dissected perianth. D — Column and lip, lateral view. E - Column, ventral view. Drawn by A.P. Karremans, based on Karremans 84 (JBL-Spirit). 
Eтymology: Referring to the concave shape of the lip.

Habitat in Costa Rica: Epiphytic in tropical wet forest along the Central Valley at about 700-800 m elevation.

Additional Costa Rican material studied: Cartago: Límite entre Turrialba y Jiménez, La Suiza, Pejivalle, camino a Esperanza, en lomas cerca de la Quebrada Puente, 9॰48'46.0”' $83^{\circ} 39^{\prime} 10.0^{\prime \prime} \mathrm{W}, 738 \mathrm{~m}$, bosque muy húmedo premontano, epífitas en bosque secundario a la orilla de cañaverales, 1 mayo 2008, $D$. Bogarin 4847, A.P. Karremans, Y. Kisel \& R. Phillips (JBL-Spirit!). Same locality and date, D. Bogarín 4848, A.P. Karremans, Y. Kisel \& R. Phillips (JBL-Spirit!; figures $3 \&$ 14D). Taus, pastures beside Río Pejibaye between Río Taus and Quebrada Azul, elev. 760 m. Epiphyte in large clumps. Flowers green. 28 May 1972, R.W. Lent 2553, (CR!, F, NY). Heredia: Sacramento, marzo 1983. Floreció en cultivo en el Jardín Lankester en julio de 1990, Mora s.n., (USJ!); San José de la Montaña, 15 marzo 1981, Mora s.n., (USJ!). Without collecting data, Jardín Botánico Lankester, received 18 March 1982, pressed cult. 7 April 1983, Hágsater 6731 (AMO), idem. pressed cult. 4 September 1984 (AMO; INB!), idem. pressed cult. 18 September 1986 (AMO), idem. pressed cult. 23 November 1992 (AMO), idem. pressed cult. 18 September 1996 (AMO).

Epidendrum concavilabium was traditionally considered a synonym of E. circinatum Ames (Hágsater et al. 2003; Jiménez \& Hágsater 2008). Although their habits are similar, plants of E. concavilabium are much more robust, more compact and thicker, have wider leaves (length:width ratio 2-3:1 vs. 4-5:1) that are darker (even in herbarium material). Both have a concave, pandurate lip, but that of E. concavilabium is much more deeply concave and shorter (19-23 mm vs. 30-32 mm). The two species have completely retrorse sepals and petals, which are similar in length (lateral sepals $16-19 \mathrm{~mm}$, petals $14-15 \mathrm{~mm}$ ); however, those of E. concavilabium are wider (lateral sepals 10-11 $\mathrm{mm}$ vs. $7-8 \mathrm{~mm}$ and petals $6-7 \mathrm{~mm}$ vs. $3.5-4 \mathrm{~mm}$ ), and generally more obtuse (vs. acute). Additionally, the column of E. concavilabium is shorter, almost as wide as long, whereas that of E. circinatum is clearly longer than wide. Aside from morphological characters, E. circinatum is typically found in the warm Caribbean lowlands with coastal influence, whereas E. concavilabium grows at higher elevations in the mountainous areas around the Central Valley.

Note: Since E. concavilabium was relegated to the synonymy of E. circinatum by Hágsater et al. (2003) and Jiménez \& Hágsater (2008), we also list the studied specimens of E. circinatum: Nicaragua. Bluefields: En los manglares frente a la costa, $0 \mathrm{~m}$ de altura. 18 febrero 2004, A.P. Karremans 84 (JBL-Spirit!; figures 4 \& 16-D). Costa Rica. Limón: Cantón de Talamanca, Bratsi. Amubri, Alto Lari, siguiendo la fila entre Río Dapari y Río Lari, bajando hasta el cauce del mismo, 9²5’30” N 8303’35” W 450 m. Epífito. Cáliz verde, corola verde-blanco, columna verde. 3 marzo 1992, G. Herrera 5159 (CR, AMO, MO, INB!). Alajuela: Arenal Volcano, 400 year old lava flow. Open high canopy, dense understory, broken lava blocks covered w/duff. April 22, 1990. V.A. Funk 10809, F.O. Smith, G.S. McKee and others (CR!). Without specific locality data, JBL-s.n. (digital photograph, 14C).

We have not been able to see material from Hágsater 6810 (AMO) and Lankester 844 (AMES), cited by Jiménez \& Hágsater (2008) under the Costa Rican specimens of E. circinatum, but based on their locality they probably are E. concavilabium.

4. Epidendrum cystosum Ames, Bot. Mus. Leafl. 2(9):105. 1934. Type: Honduras. Yoro: Bajo Grande, 3000 ft, 14 March 1934, J. B. Edwards 675 (holotype: AMES; photo of type at AMES!; illustration of type!).

Distribution: Mexico, Belize, Honduras, Nicaragua, Costa Rica and Colombia.

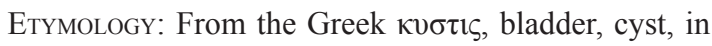
reference to the prominent ventral vesicle behind the perianth.

Habitat in Costa Rica: the only known specimen was found growing as an epiphyte on a solitary tree in open pastures, in tropical wet forest, just above sea level around Drake Bay in the Península de Osa.

Costa Rican material studied: Puntarenas: Osa, Sierpe. Bahía Drake, frente a Finca Maresía, en árboles de potrero, bosque muy húmedo tropical, $8^{\circ} 40^{\prime} 49.9^{\prime \prime} \mathrm{N}$ 8340'17.5” W, 85 m, 19 marzo 2011, A.P. Karremans 3744 \& M. Contreras (JBL-Spirit!, CR!; figures 5, 14E). 
B

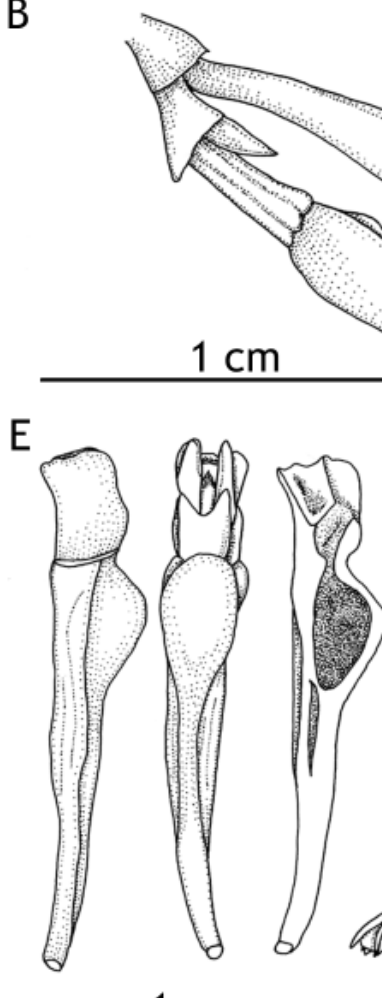

D
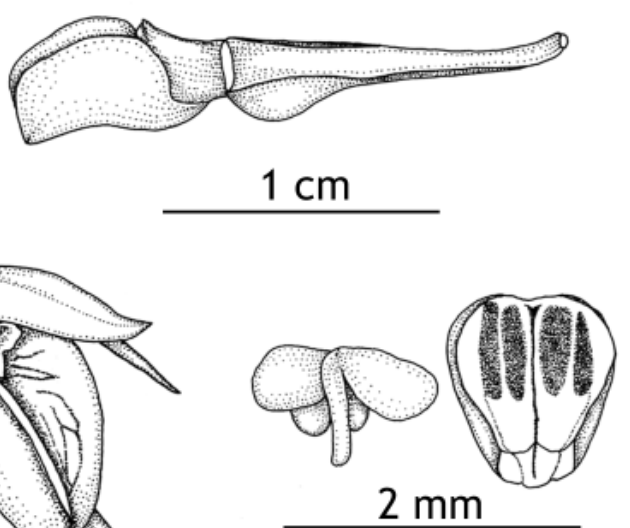

A


$2 \mathrm{~mm}$

$1 \mathrm{~cm}$

C
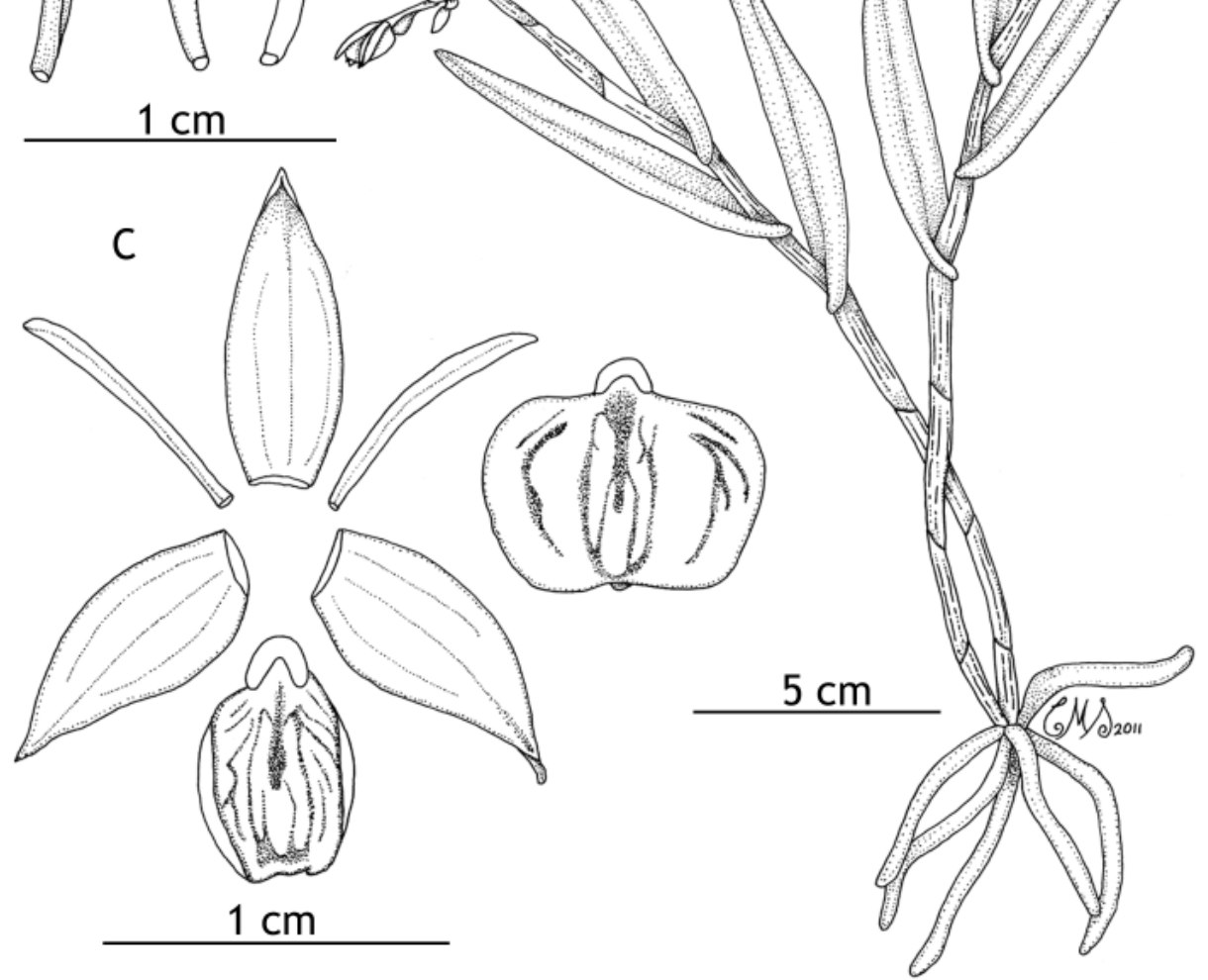

Figure 5. Epidendrum cystosum Ames. A - Habit. B - Flower. C - Dissected perianth, with lip in natural configuration below and spread to the right. D - Column and lip, lateral view. E - Column, lateral view, front view, and longitudinal section (from left to right). F - Pollinarium and anther cap. Drawn by C. M. Smith based on Karremans 3744 (JBL-Spirit). 
This unique species is distinguished by the thin stems, grassy leaves, inflorescence generally shorter than the apical leaf, with partly spreading petals and sepals, the apices of the sepals recurved, the elliptical to suborbicular lip with evident laminar keels, and the prominent clinandrium-hood with the margin erose. Epidendrum cystosum is most similar to E. macroclinium Hágsater, but the latter has succulent, ovate-lanceolate leaves, inflorescences much longer that the apical leaf, reflexed petals, an obreniform lip with a single low keel, and a prominent clinandriumhood with a fimbriate-dentate margin. It may also be related to E. physodes Rchb.f., which can be distinguished by the wider, lanceolate, short-acuminate leaves, the inflorescence longer than the apical leaf, the lip transversely elliptic, with a single low keel, and an obsolete clinandrium-hood with a thick and crenate margin (Santiago \& Hágsater 2010).

\section{Epidendrum $\times$ sandiorum Hágsater, Karremans \& L.Sánchez, nothosp. nov.}

Type: Costa Rica. Puntarenas: Coto Brus, Sabalito, Zona Protectora Las Tablas, $10 \mathrm{~km}$ al noreste de Lucha, Sitio Coto Brus, camino a la Finca de Miguel Sandí, 8०56'07.4” N 8245'13.9” W, $1862 \mathrm{~m}$, bosque muy húmedo montano bajo, epífitas a orillas del camino, colectado 5 junio 2010, floreció en cultivo en agosto 2011, A. P. Karremans $2781 \&$ D. Bogarin (holotype, JBL-spirit!; figure 13).

Planta inter Epidendrum ciliare L. et E. oerstedii Rchb.f. quasi intermedia et verisimiliter ex hybridatione harum specierum orta, cum Epidendro ciliare sed lobulo apicali labelli ad medium dilatato, lanceolato, clavato, manifeste acuminato, margine vix eroso, cum Epidendro oerstedii sed lobulis lateralibus labelli margine profunde fimbriato ad laciniatum, lobo apicali labelli longiore et aliis characteribus inter parentes mediis.

Epiphytic, sympodial, caespitose herb, up to 20 $\mathrm{cm}$ tall. Roots basal, fleshy, $3 \mathrm{~mm}$ in diameter. Stems thickened into a sub-spherical to ovoid homoblastic pseudobulb, $4.0-6.0 \times 1.5-3.0 \mathrm{~cm}$. Leaves 1 at the apex of the pseudobulb, coriaceous; blade ovate-elliptic, bilobed, 7.5-12.0 × 3.5-6.0 cm. Spathaceous bract lacking. Inflorescence apical, racemose, born from the undeveloped new growth, with at least 3 flowers; peduncle laterally compressed, $2.5 \mathrm{~cm}$ long; covered by triangular, obtuse bracts. Floral bract about half the length of the ovary, triangular, acuminate, 3.5 $\mathrm{cm}$. Ovary terete, not inflated, smooth, exceeding the length of the sepals, $6.5 \mathrm{~cm}$. Flowers simultaneous, resupinate, sepals and petals yellowish green, lip white, column white turning green close to the base, calli white; flowers turn completely yellow with age. Sepals spreading, narrowly elliptic-lanceolate, acuminate, 5-7 veined, margin entire, revolute, $5.5 \times$ $0.9 \mathrm{~cm}$. Petals incurved, embracing the column and lip, linear-lanceolate, acuminate, 5-veined, margin entire, $5.2 \times 0.8 \mathrm{~cm}$. Lip basally united to the column, 3-lobed, base truncate; bicallose, the calli laminar, prominent, narrowly elliptic, $5 \mathrm{~mm}$; disc with numerous evident veins; lateral lobes obliquely oblong, inner margin entire, outer margin prominently fimbriate to laciniate, $20 \times 6 \mathrm{~mm}$; mid-lobe separate from the lateral lobes by deep sinuses, lanceolate-clavate, widened beyond the middle and that portion trullate, acuminate, margin shallowly erose, $45 \times 7 \mathrm{~mm}$. Column straight, dilated towards the apex, $1.6 \mathrm{~cm}$ long; clinandriumhood prominent, margin dentate-fimbriate, rostellum apical, cleft, forming a slit-like aperture anther ovoid, 4-celled. Pollinia 4, obovoid, the inner margin straight, laterally compressed.

Distribution: Known only from Costa Rica; however, as it was found a few $\mathrm{km}$ from the border it could also occur in Panama.

Etymology: The name honors Miguel Sandí and his family; the plant that served as the type was collected on the road leading to their property.

Habitat in Costa Rica: This natural hybrid is only known from the very humid lower montane forests of the Pacific watershed of the Cordillera de Talamanca at an elevation of around $1900 \mathrm{~m}$.

Phenology: Flowering at least in August and September in cultivation.

Several species of Epidendrum (e.g., E. ciliare L. E. falcatum Lindl., E. nocturnum L., E. oerstedii Rchb.f., and E. parkinsonianum Hook.) have starlike, white or greenish flowers with a deeply 3-lobed, white lip. They were traditionally considered close 
relatives, but DNA studies (Hágsater \& Soto 2005b) showed that species with this floral morphology are found in five different groups within Epidendrum, and that probably their pollination by nocturnal sphyngid moths has led to the development of similar floral features. The fact that they may all be pollinated by the same type of moth has led to occasional natural hybrids, such as E. parkinsonianum $\times$ E. falcatum (Hágsater 1990) and Epidendrum $\times$ dorotheae P.H. Allen (Hágsater \& Sánchez 2008a). The latter case is interesting because the putative parent species belong to different groups, E. nocturnum being in the Nocturnum group and E. ciliare in the Coilostylis Group.

Both putative parents of Epidendrum $\times$ sandiorum, E. oerstedii and E. ciliare, are members of the Coilostylis Group that is characterized by the sympodial, caespitose plants, the stems forming a fusiform pseudobulb, with an apical, racemose, distichous inflorescence, the peduncle covered by large bracts (but not spathaceous), and flowers with the above-mentioned morphology. The hybrid is recognized by the sub-spherical to ovoid pseudobulbs with a single apical leaf and the inflorescence produced from the immature stem. The outer margins of the lateral lobes of the lip are fimbriate to laciniate, the mid-lobe trullate beyond the middle, $45 \mathrm{~mm}$ long, apically long-acuminate, and the margin erose. Epidendrum oerstedii ranges from Honduras to central Panama, produces the inflorescence from the immature, short pseudobulb. The margin of the lip is entire, and the mid-lobe shorter (25-33 mm long), widened beyond the middle. Epidendrum ciliare is widely distributed from western Mexico (Nayarit) south to Peru and Brazil and the Antilles, also produces the inflorescence from the immature, more elongate pseudobulb, but the outer margins of the lip are deeply fimbriate, and the mid-lobe is linear, not widened in the middle (Sánchez \& Hágsater 2008b; 2010). The putative parents have not been recorded yet at the same location were the hybrid was found.

\section{Epistephium ellipticum R.O.Williams \&}

Summerh., Bull. Misc. Inform. Kew 1928(4): 145. 1928. Type: Trinidad: Valencia Road, Mora forest end, Sept. 1926, Freeman, William \& Cheesman s.n. (holotype, TRIN no. 11324; isotype, K).
Distribution: Belize, Costa Rica, Venezuela, Trinidad, Guyana and Peru. Likely occurs (but not yet collected) in Colombia, Ecuador, Panama, and other Central American countries.

Eтymology: From the Latin ellipticus, elliptic, in reference to the elliptic leaf shape of the type specimen.

Habitat IN Costa Rica: Known from a single collection in the coastal lowlands of the Caribbean close to the Panamanian border. The specimen label does not describe the habitat, but species of Epistephium grow terrestrially, typically in open, grassy areas (Cameron 2003).

Costa Rican material studied: Limón. Talamanca, Sixaola, Gandoca, El Llano entre Filas Manzanillo y Rio Mile Creek. 09³7’00” N, 8241'00” W, 50-100 m. 27 Mar. 1995. Terrestre. Margen de la hoja liliáceos. Flor lila morado. G. Herrera 7605 \& E. Sandoval Mc Carthy (CR!, MO; figure 6).

Heretofore, E. ellipticum had been recorded for Belize, Venezuela, Trinidad, Guyana and Peru; it had not been recorded from anywhere in Central America outside of Belize. The Costa Rican record here reported was collected a few kilometers from the Panamanian border, and the species likely occurs in Panama as well. The duplicate specimen at MO had already been identified as E. ellipticum by Robert L. Dressler in 2007.

Epistephium ellipticum is a short-statured herb and the flowers of the genus are short-lived (Garay 1961), so the plants are likely overlooked and undercollected. In addition, because of their reticulate leaf venation, herbarium collections are likely to be erroneously assigned to other plant families (e.g., Convallariaceae, Smilacaceae, or even Piperaceae) when not in flower or when the perianth has been damaged or lost. It is possible that E. ellipticum is more widespread along the Caribbean lowlands of Central America than what the few available collections suggest. Epistephium ellipticum is also known from Peru from a single collection made in the Amazonian lowlands of the department of Loreto (Beltrán \& Foster 567, F). No collections of the Amazonian lowlands of Colombia and Ecuador are known to us. The size variation of the three plants included in the herbarium sheet at CR (all of them with inflorescences) is worth mentioning; two plants are only $8 \mathrm{~cm}$ tall, whereas the third plant is $23 \mathrm{~cm}$ tall. 


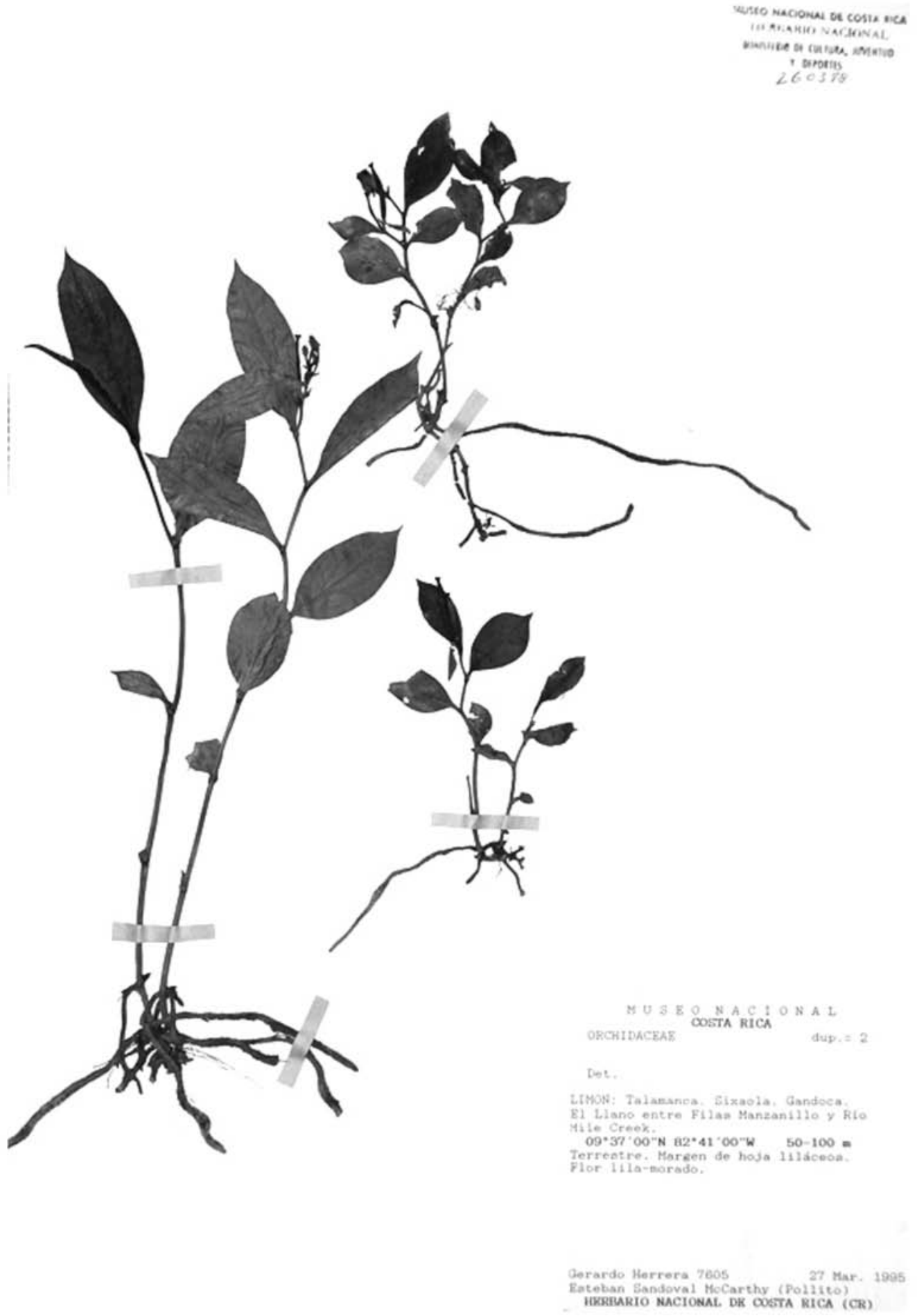

FiguRE 6. Herbarium specimen of Epistephium ellipticum R.O.Williams \& Summerh. (Herrera 7605 \& Sandoval McCarthy, $\mathrm{CR})$. 
7. Lepanthes kabebatae Bogarín, Karremans \& Mel. Fernández, sp. nov.

Type: Costa Rica. Cartago: Turrialba, La Suiza, Llanos del Quetzal, ca. $1 \mathrm{~km}$ sobre el camino detrás de la Escuela de Kabebata (Alto Quetzal), 9 $46^{\prime} 43.6^{\prime \prime} \mathrm{N}$ $83^{\circ} 24^{\prime} 41.6^{\prime \prime} \mathrm{W}, 1449 \mathrm{~m}$, epífita en bosque primario y secundario, bosque muy húmedo premontano, "supra arbores in nemoribus Llanos del Quetzal ad Turrialba in Cartago", 17 junio 2011, D. Bogarin 8873, M. Fernández \& A.P. Karremans (holotype, CR; isotype, JBL-Spirit; figures 7, 14F).

A Lepanthes eleganti Luer petalis latioribus luteis basaliter scarlatis, lobo superno petalorum oblongovato, lobo infero petalorum angusto-ovato, labello scarlato minute ciliato et appendice longiore statim dignoscenda.

Epiphytic, caespitose, erect herb, up to $20 \mathrm{~cm}$ tall. Roots slender, flexuous, to $1 \mathrm{~mm}$ in diameter. Ramicaul erect to suberect, up to $12.5 \mathrm{~cm}$, enclosed by $8-11$ minutely ciliate, blackish, lepanthiform sheaths, lightly ciliate especially on new growth, the ostia dilated, ciliate, ovate, acute, adpressed. Leaves subcoriaceous, adaxially green, abaxially purple, elliptic to narrowly ovate, acute to acuminate, with an apiculus, 4.3-7.2 $\times$ 1.5-3.6 $\mathrm{cm}$, the cuneate base narrowing into a petiole up to $5 \mathrm{~mm}$ long. Inflorescence racemose, distichous, successively flowered, born beneath the leaf, shorter than the leaves, up to $4.5 \mathrm{~cm}$, peduncle $2 \mathrm{~cm}$ long, rachis $2.5 \mathrm{~cm}$. Floral bracts $1 \mathrm{~mm}$ long, ciliate, ovate, acuminate, conduplicate, membranaceous, muriculate. Pedicel $5 \mathrm{~mm}$ long, persistent. Ovary up to $3 \mathrm{~mm}$ long, glabrous. Flowers with the sepals light yellow, basally light red, petals yellow, basally scarlet, the lip scarlet. Dorsal sepal ovate, acute, connate to the lateral sepal for about $1 \mathrm{~mm}, 4.7 \times 5.1 \mathrm{~mm}$. Lateral sepals ovate to elliptic, acute, connate for about $2 \mathrm{~mm}, 4.3-4.9 \mathrm{~mm} \times$ 1.9-2.3 mm. Petals minutely pubescent with the margins minutely ciliate transversely bilobed, $1.8-2 \times 5.6-8 \mathrm{~mm}$, the upper lobe oblong-ovate, obtuse, the apex folded, the lower lobe, narrowly ovate, acute, slightly smaller than the upper lobe. Lip bilobate, adnate to the column, 1.8-2 $\mathrm{mm} \times 4.2-5 \mathrm{~mm}$, the blades oblong, minutely pubescent, with rounded ends, falcate, the connectives terete, up to $1 \mathrm{~mm}$ long, the body oblong, connate to the base of the column, the appendix oblong, pubescent. Column cylindrical, up to $2 \mathrm{~mm}$ long, the anther apical, the stigma ventral; anther cap cucullate. Pollinia two, ovoid.

Distribution: Known only from the type locality in Costa Rica.

Etymology: After the Cabécar kabe, quetzal, and bata, slope, referring to the locality of the Alto Quetzal (Kabebata), where the type specimen was collected. The Cabécar is one of the six native languages of the Chibcha language family spoken in Costa Rica.

Habitat in Costa Rica: Epiphytic in secondary and primary vegetation in premontane wet forest on the Caribbean slopes of the Cordillera de Talamanca, northwestern Fila de Matama at around $1500 \mathrm{~m}$ elevation.

Phenology: Plants have been recorded in flower at least in June, but continued flowering up to November in cultivation.

Paratypes: Costa Rica. Same locality and date as the holotype, D. Bogarín 8875, M. Fernández \& A.P. Karremans (JBL-spirit!; figure 14G). Same locality and date, A.P. Karremans 4278, D. Bogarin \& M. Fernández (JBL-spirit!; CR!). Same locality and date, A.P. Karremans 4279, D. Bogarín \& M. Fernández (USJ!)

Lepanthes kabebatae is one of the largest species of the genus in Costa Rica, with plant up to $20 \mathrm{~cm}$ tall. The flowers of $L$. kabebatae are similar to those of L. elegans, but the former can be recognized by the wider petals $5.6-8 \mathrm{~mm}$ (vs. up to $5 \mathrm{~mm}$ ) with the upper lobe oblong-ovate (vs. widely ovate) and the lower lobe narrowly ovate (vs. obliquely triangular), the microscopically ciliate lip (vs. long ciliate lip towards the apex) and the large appendix (vs. reduced to a tuft of cilia). The color of the flowers is also different; in L. kabebatae the petals are yellow, basally stained with scarlet (vs. yellow with a red stain in the middle of the upper lobe and along the external margins) and the lip is scarlet (vs. yellow).

The size and habit of L. kabebatae are similar to those of $L$. atrata Endrés ex Luer, L. barbosae Luer, L. daniel-jimenezii Bogarín \& Pupulin, L. ferrelliae Luer and L. guardiana Endrés ex Luer. However, the new species lacks the thick, protuberant body of the lip present in all those species. 

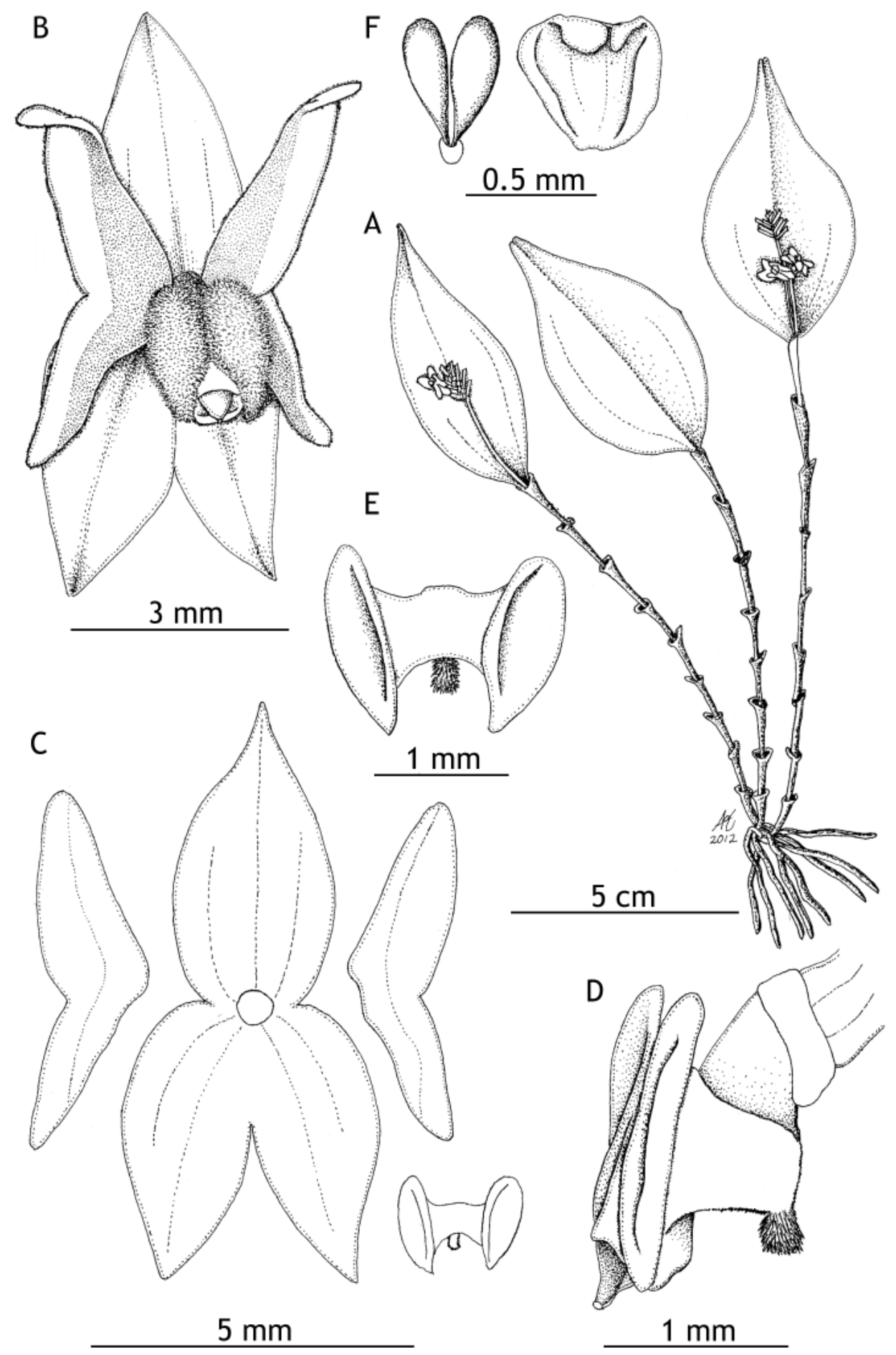

Figure 7. Lepanthes kabebatae Bogarín, Karremans \& Mel. Fernández. A — Habit. B — Flower. C — Dissected perianth. D - Column and lip, lateral view. E - Lip, spread. F. Pollinarium and anther cap. Drawing by D. Bogarín and A.P. Karremans, based on the plant used as type (JBL-Spirit). 
9. Lepanthes psyche Luer, Phytologia 55: 192. 1984. Type: Panama. Chiriquí, epiphytic in small trees near Volcán, "La Cordillera", alt. 1300 m, 9 Dec. 1983, C. Luer, J. Luer, A. Maduro \& H. Butcher 9317 (holotype, SEL). Lepanthes setos Luer, Phytologia 55(3): 193-194. 1984. Type: Panama. Prov. of Chiriquí: epiphytic in scrubby trees near Volcán, alt. 1350 m, 7 Dec. 1983, C. Luer, J. Luer \& H. Butcher 9279 (holotype, SEL).

Distribution: Costa Rica and Panama.

Eтymology: From the Greek psyche, a butterfly, in reference to the large petals.

Habitat in Costa Rica: Epiphytic in secondary premontane wet and transition to wet forests in the southern Pacific watershed of the Cordillera de Talamanca at around $1500 \mathrm{~m}$ elevation.

Costa Rican material studied: Puntarenas: Coto Brus, Sabalito, Cotoncito, Sitio Cotón, 856’34.07” N $82^{\circ} 47$ '15.55" W, $1545 \mathrm{~m}$, en árboles a orillas de una quebrada, Daniel Jiménez invenit, floreció en cultivo en el Jardín Botánico Lankester, 7 abril 2011, D. Jiménez sub D. Bogarín 8538 (JBL-Spirit!; figures 8, 14H). San José: Dota, San Lorenzo de Dota, camino que comunica esa localidad con el proyecto Pirrís, parte más alta del trayecto, árboles de Ciprés en cerca de potreros, 9036'45.72'N 8404'51.88'”, recolectada por D. Jiménez, M. Fernández 334 (JBL-spirit!).

This species is closely related to Lepanthes fimbriata Ames. Vegetatively they are similar, both having thick, heavy, concave, coppery leaves with pendent stems. The appendix is conspicuous and fimbriate in both species. However, L. psyche is distinguished from $L$. fimbriata by the glabrous petals and lip (vs. fimbriate) and the petals with the upper lobe suborbicular to widely obovate (vs. ovate). Lepanthes setos Luer from Panama is considered a synonym of $L$. fimbriata (Luer 2003).

10. Lepanthes regularis Luer, Lindleyana 2: 210. 1987. Type: Panama. Prov. of Chiriquí: Cerro Punta, Las Nubes, collected by A. Maduro 6-B, $C$. Luer 11631 (holotype, MO).

Distribution: Costa Rica and Panama.

Eтymology: From the Latin regularis, regular, standard, referring to the average morphology of this species.

Habitat in Costa Rica: Epiphytic in disturbed forest in pastures in lower montane rain forests in the southern Pacific watershed of the Cordillera de Talamanca, at around $1800 \mathrm{~m}$ elevation.

Costa Rican material studied: Puntarenas: Coto Brus, Sabalito, Zona Protectora Las Tablas, $13 \mathrm{~km}$ al noreste de Lucha, Sitio Coto Brus, entre Río Surá y Quebrada Sutú, Finca de Miguel Sandí, 856’46.1” N 8244'30.9" W, $1778 \mathrm{~m}$, bosque pluvial montano bajo, epífitas en potreros arbolados, 6 junio 2010,D. Bogarín 7767 \& A.P. Karremans (JBL-Spirit!; figures 9, 14I). Puntarenas: Coto Brus, Sabalito, Zona Protectora Las Tablas, $13 \mathrm{~km}$ NE of Lucha, Sitio Coto Brus, finca Sandí "El Capricho", 856’46.1” N 8244’30.9” W, 1778 m, epiphytic, mostly on Quercus sp. in pastures and along the river Sutú, wet premontane forest, 6 October 2010, F. Pupulin 7928, D. Bogarín, R.L. Dressler \& M. Fernández (JBL-spirit!; CR!).

According to Luer (1987) the morphological features of this species are standard for the genus and no one character is particularly distinctive, it is actually the combination of standard characters that make L. regularis unique. A population of this species was found near the border between Costa Rica and Panama in the region of Las Tablas (15 km from the type locality of Las Nubes in Panama). The features are consistent with those given in the protologue (Luer 1987), especially in the ovate, acute lateral sepals, the red oblong petals, the minutely pubescent appendix and the general measurements of the flower parts and plant.

11. Masdevallia nicaraguae Luer, Selbyana 5(2): 148-149. 1979. Type: Nicaragua. Granada: epiphytic in cloud forest on Mombacho Volcano, J.T. Atwood s.n., cultivated by J. \& L. Orchids, Easton, CT, flowered in cult. 7 Nov 1977, C. Luer 2118 (holotype, SEL).

Distribution: Nicaragua and Costa Rica.

EтумоLоgy: Named after Nicaragua, the country of origin of the type specimen.

Habitat in Costa Rica: The only known specimen of 

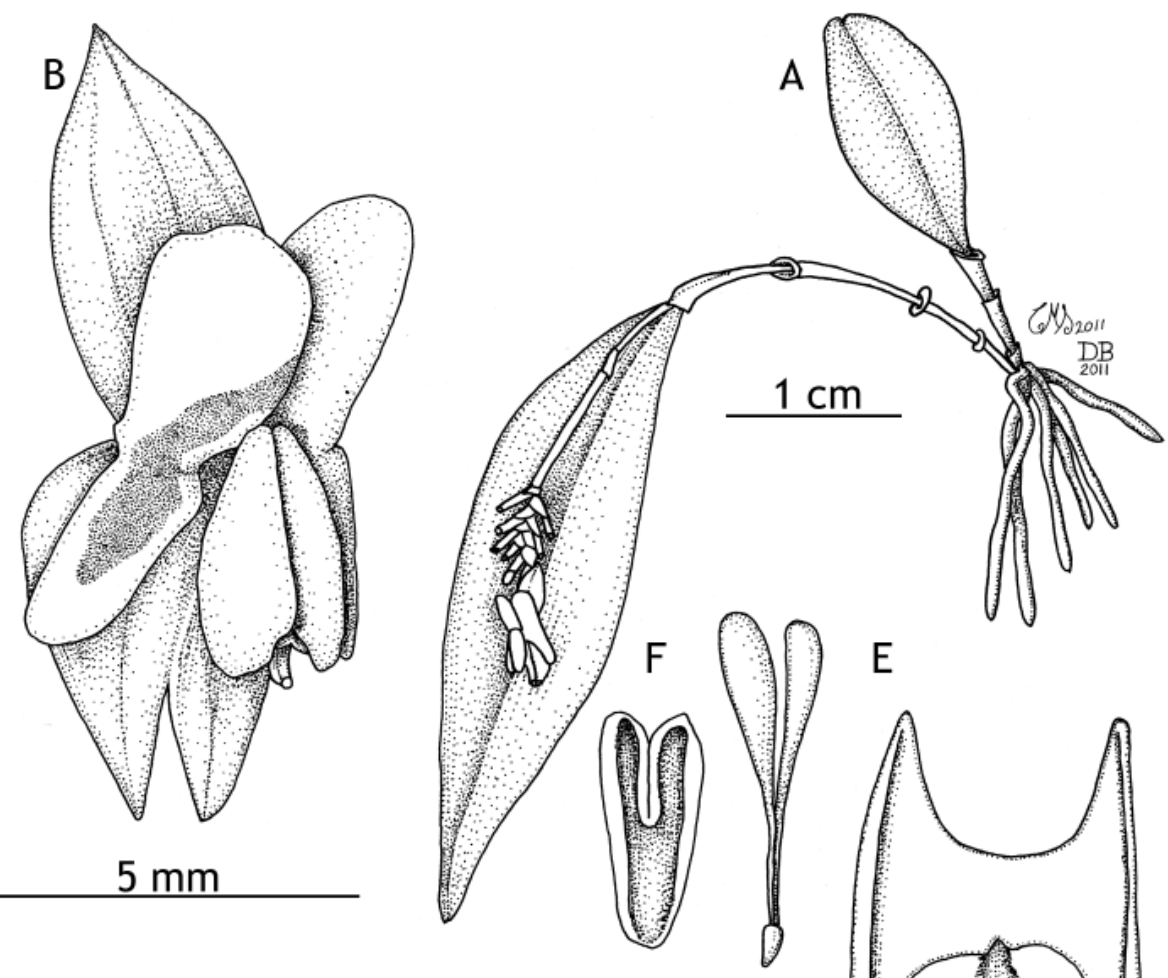

$E$
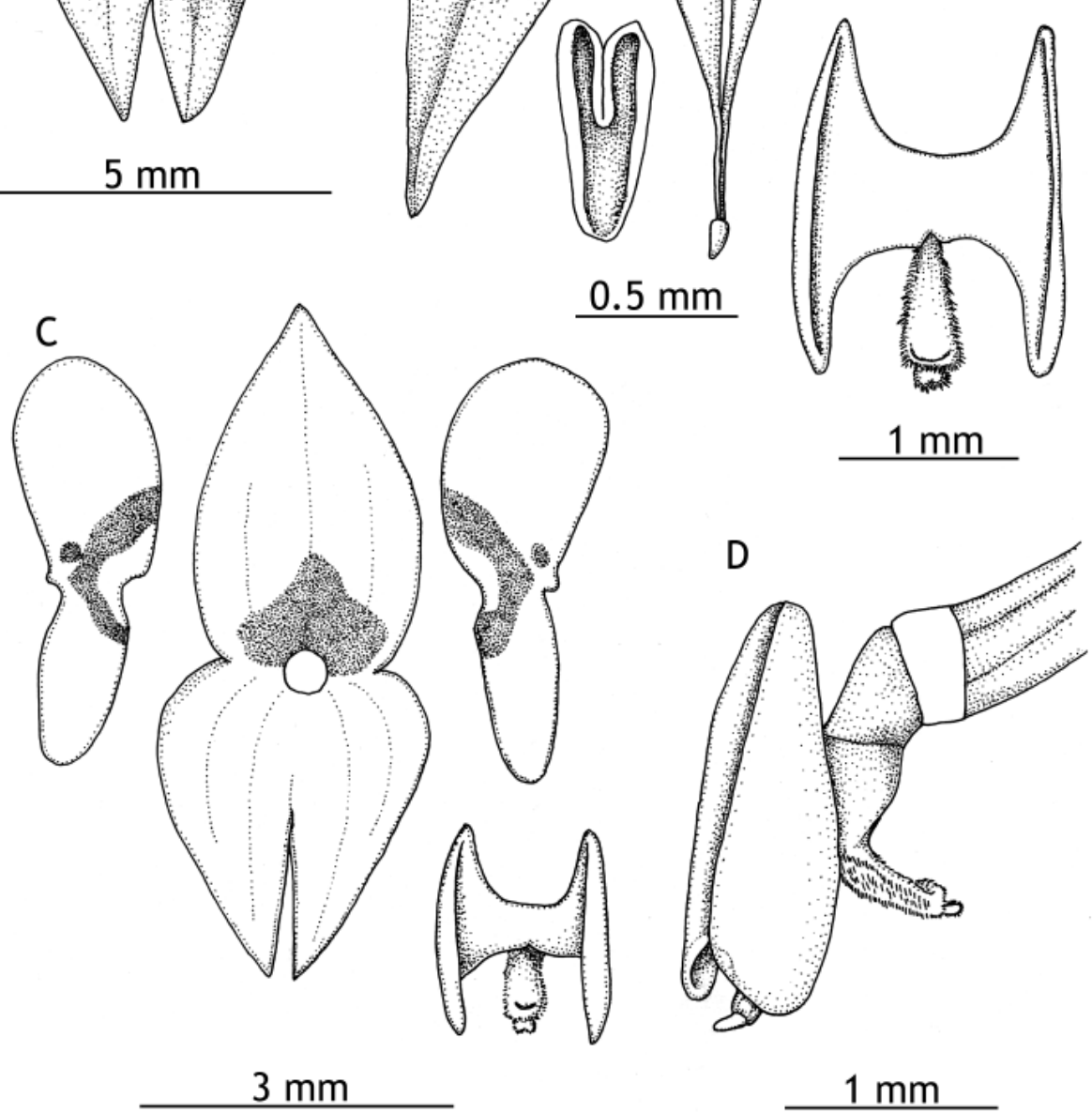

Figure 8. Lepanthes psyche Luer. A - Habit. B - Flower. C - Dissected perianth. D - Column and lip, lateral view. E - Lip, spread. F — Pollinarium and anther cap. Drawing by D. Bogarín and C. M. Smith based on Bogarín 8538 (JBLspirit). 

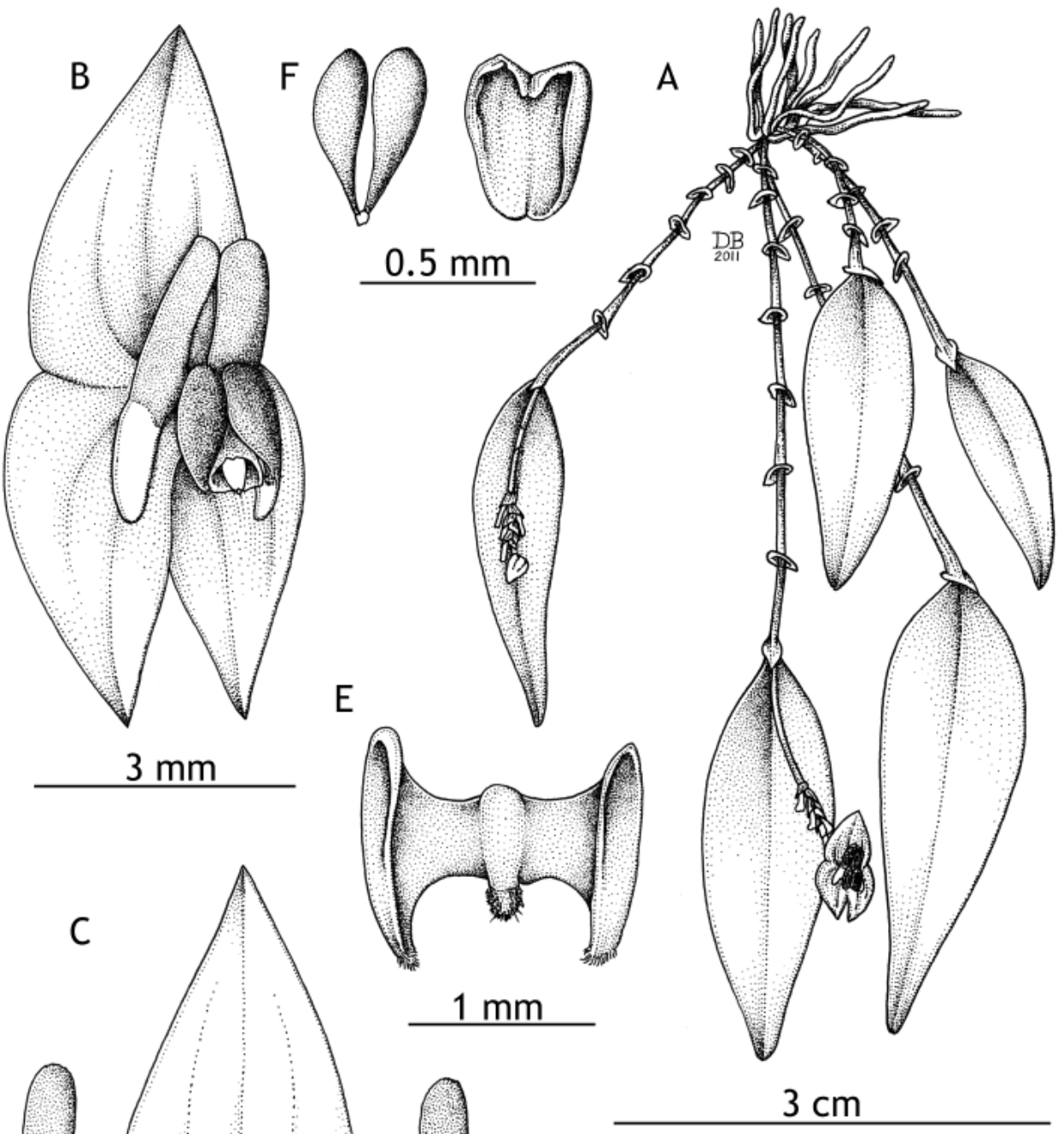

E
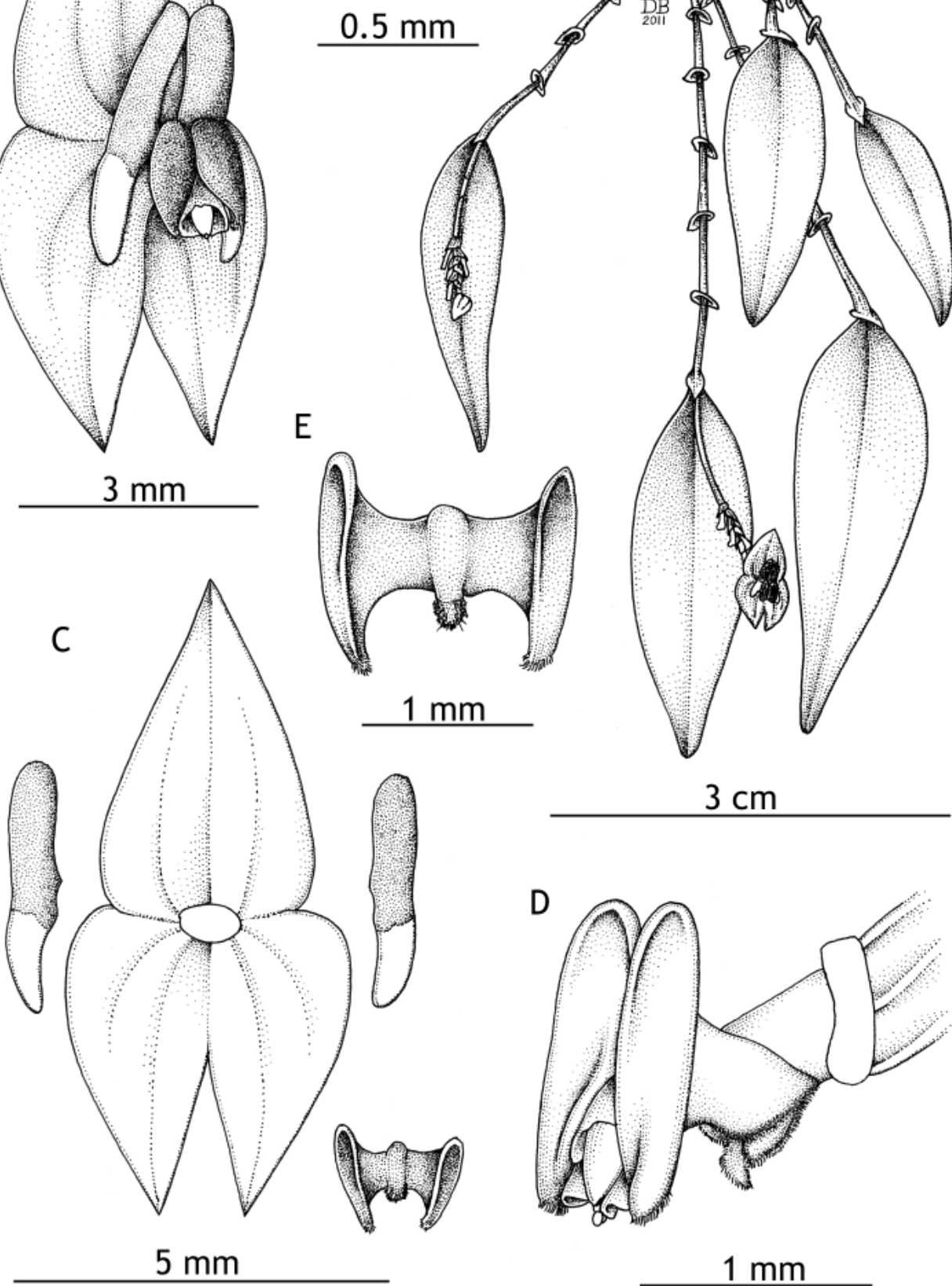

Figure 9. Lepanthes regularis Luer. A - Habit. B - Flower. C - Dissected perianth. D - Column and lip, lateral view. E - Lip, spread. F — Pollinarium and anther cap. Drawing by D. Bogarín based on Bogarín 7767 (JBL-spirit). 

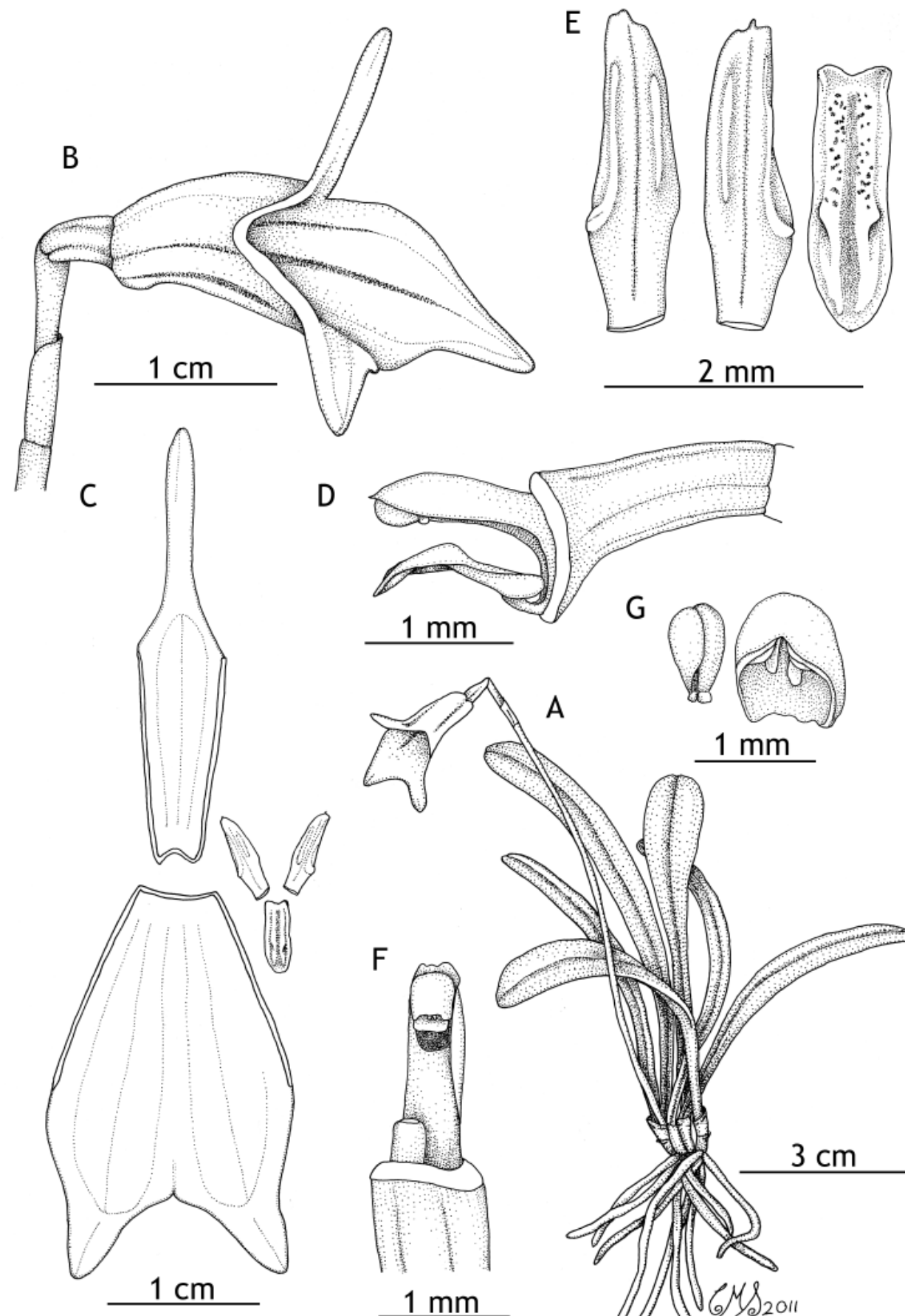

$2 \mathrm{~mm}$
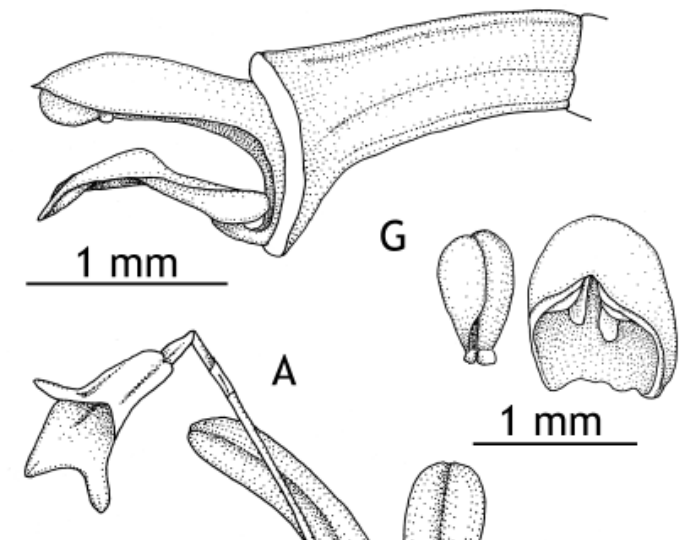

$\mathrm{F}$

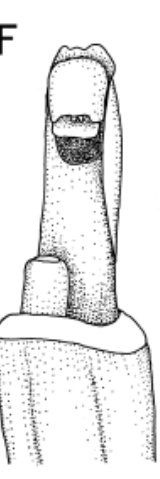

$1 \mathrm{~mm}$

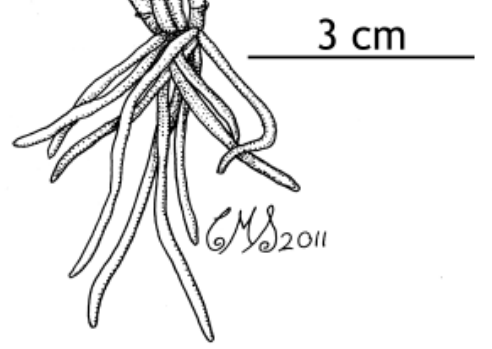

FiguRe 10. Masdevallia nicaraguae Luer. A - Habit. B - Flower. C - Dissected perianth. D - Column and lip, lateral view. E - Petals and lip. F - Column and bases of ovary and lip. G - Pollinarium and anther cap. Drawn by C. M. Smith based on Acosta s.n. (JBL-spirit). 
M. nicaraguae was found growing in premontane wet forest, around Río Costa Rica in Guápiles at $600 \mathrm{~m}$ elevation. It is likely that this species would turn up in the northern Caribbean lowlands of Costa Rica, which are continuous with the Nicaraguan lowlands where plants of this species are known to grow..

Costa Rican material studied: [Costa Rica: Limón: Pococí, Guápiles] Río Costa Rica, 600 m, L. Acosta s.n. (JBL-Spirit D2166!, D2264!, D1988!; figures 10, $14 \mathrm{~J})$.

This species is similar to Masdevallia floribunda Lindl., from which it is distinguished by the thick sepaline tails, particularly those of the shorter, triangular, lateral sepals, white, faintly suffused with rose within toward the bases (vs. dull brownish yellow, spotted). Masdevallia nicaraguae is also similar to $M$. tubuliflora Ames, but is distinguished by its larger, pure white sepals, the erect tail of the dorsal sepal, the broadly dilated lateral sepals and the entire apex of the column (Luer 2001).

12. Pleurothallis instar Luer, Selbyana 3: 320-321, f. 260. 1977. Type: Panama. Chiriquí: epiphytic in cloud forest on Cerro Hornito, alt. ca. $1700 \mathrm{~m}$, 15 Dec 1976, C. Luer 1389, A. Luer, R.L. Dressler, N.H. Williams \& F.L. Stevenson (holotype, SEL; illustration of type!).

Distribution: Panama and Costa Rica.

Etymology: From the Latin instar, image, likeness, in reference to the similarity of the plant to Pleurothallis eumecocaulon Schltr.

Habitat in Costa Rica: Both plants of Pleurothallis instar were found growing epiphytically in the premontane rain forests of the Fila Cruces, in the Pacific watershed.

Costa Rican material studied: Puntarenas: Coto Brus, Limoncito, Fila Cruces, camino al Cerro Paraguas, ca. $10 \mathrm{~km}$ al oeste del Jardín Botánico R. \& C. Wilson sobre el camino a Río Claro de Golfito, 8०46'22.4” N 82॰59'33.1” W, $1367 \mathrm{~m}$, bosque pluvial premontano, epífitas en bosque secundario a orillas del camino, 5 junio 2010, A.P. Karremans 2776 \& D. Bogarín (JBL-Spirit!; figure 11, 14K). Same locality, 20 abril 2011, D. Bogarin 8742, D.
Jiménez \& A.P. Karremans (JBL-Spirit!).

As indicated in the protologue, Pleurothallis instar resembles mostly closely $P$. eumecocaulon Schltr., but it can be recognized by the ovate leaves and wider sepals and petals. Also, P. eumecocaulon bears a papillose disc located below the middle of the lip, whereas the disc in P. instar is concave and located in the basal half. Luer (2004) moved P. eumecocaulon to Ancipitia Luer but seems to have forgotten P. instar.

13. Specklinia duplooyi (Luer \& Sayers) Luer, Monogr. Syst. Bot. Missouri Bot. Gard. 95: 260. 2004. Pleurothallis duplooyi Luer \& Sayers, Revista Soc. Boliv. Bot. 3(1/2): 48-50. 2001. Panmorphia duplooyi (Luer \& Sayers) Luer, Monogr. Syst. Bot. Missouri Bot. Gard. 105: 153. 2006. Type: Belize. Toledo District, Little Quartz Ridge Camp, alt. 740 m, 1 August 2000, B. Sayers 997 (holotype, DBN; isotype, MO).

Distribution: Belize and Costa Rica.

Eтymology: Named in honor of the late Ken DuPlooy, former director of the Belize Botanical Garden, who had a keen interest in the flora of Belize.

Habitat in Costa Rica: Epiphytic on twigs of abandoned trees of Macadamia integrifolia (Proteaceae) in premontane rain forest, on the Caribbean watershed of the Cordillera de Talamanca at around 700 m elevation.

Costa Rican material studied: Cartago: Jiménez, Pejibaye, Taus, Río Pejibaye, 1 km después de la escuela de Taus, 946'51.7' $\mathrm{N} 83^{\circ} 43^{\prime} 00.4^{\prime \prime} \mathrm{W}, 707 \mathrm{~m}$, bosque pluvial premontano, epífita en bosque secundario a orillas del río, 30 abril 2009, D. Bogarín 6955, M. Fernández, R. Gómez, Y. Kisel, F. Pupulin, P. Renshaw $\& R$. Trejos (JBL-Spirit). Same locality, 16 octubre 2009, D. Bogarín 7382 \& A.P. Karremans (JBLSpirit!). Same locality and date, D. Bogarín $7384 \&$ A.P. Karremans (JBL-Spirit!; figures 12, 14L). Same locality, 29 de enero 2012, A.P. Karremans 4887, R.J.C.M. \& I.V. Ferreira Lok (JBL-Spirit!).

The species was previously known only from Belize. It is closely related to the widely distributed Specklinia barbulata (Lindl.) Luer, from which it is distinguished by the larger inflorescences surpassing the leaves (vs. as long as or shorter than the leaves), 

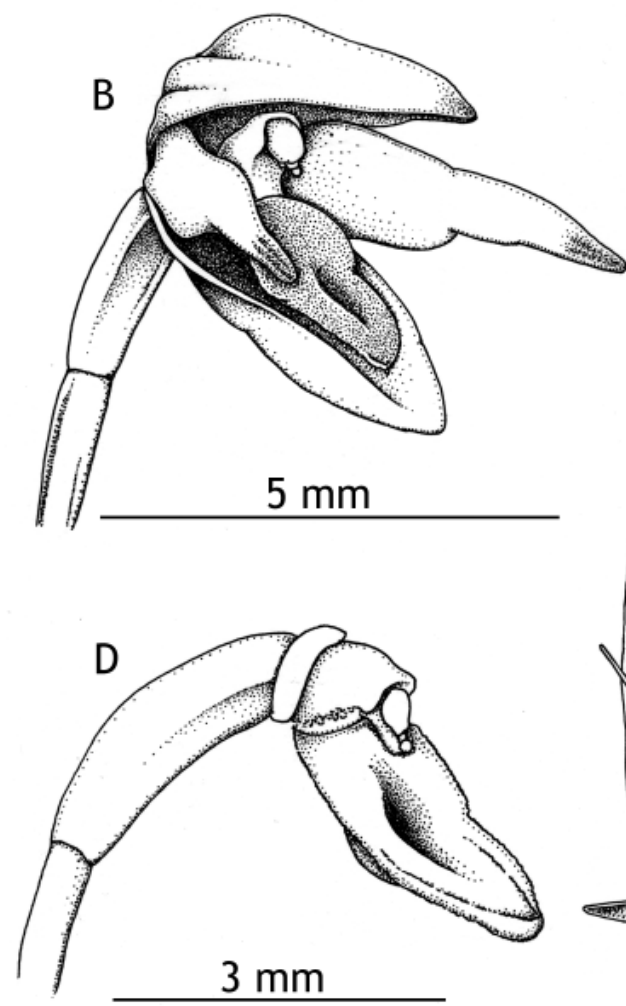

$\mathrm{G}$


FiguRe 11. Pleurothallis instar Luer. A - Habit; B - Flower; C - Dissected perianth; D — Column and lip, oblique view; E - Lip, ventral view; F — Detail of lip apical margin, G — Pollinaria. Drawn by M. Fernández based on Karremans 2776 (JBL-spirit). 


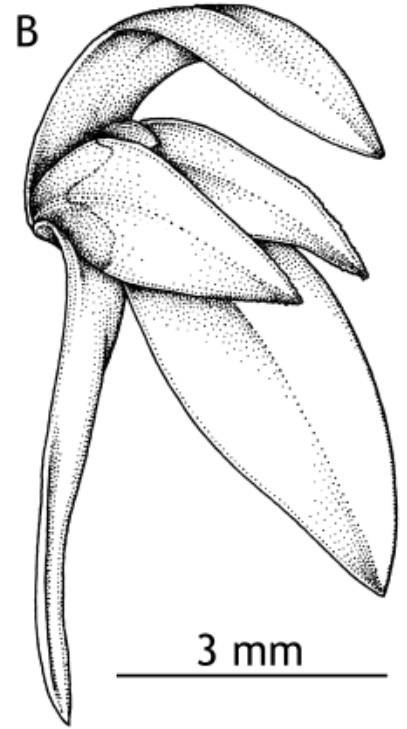

G
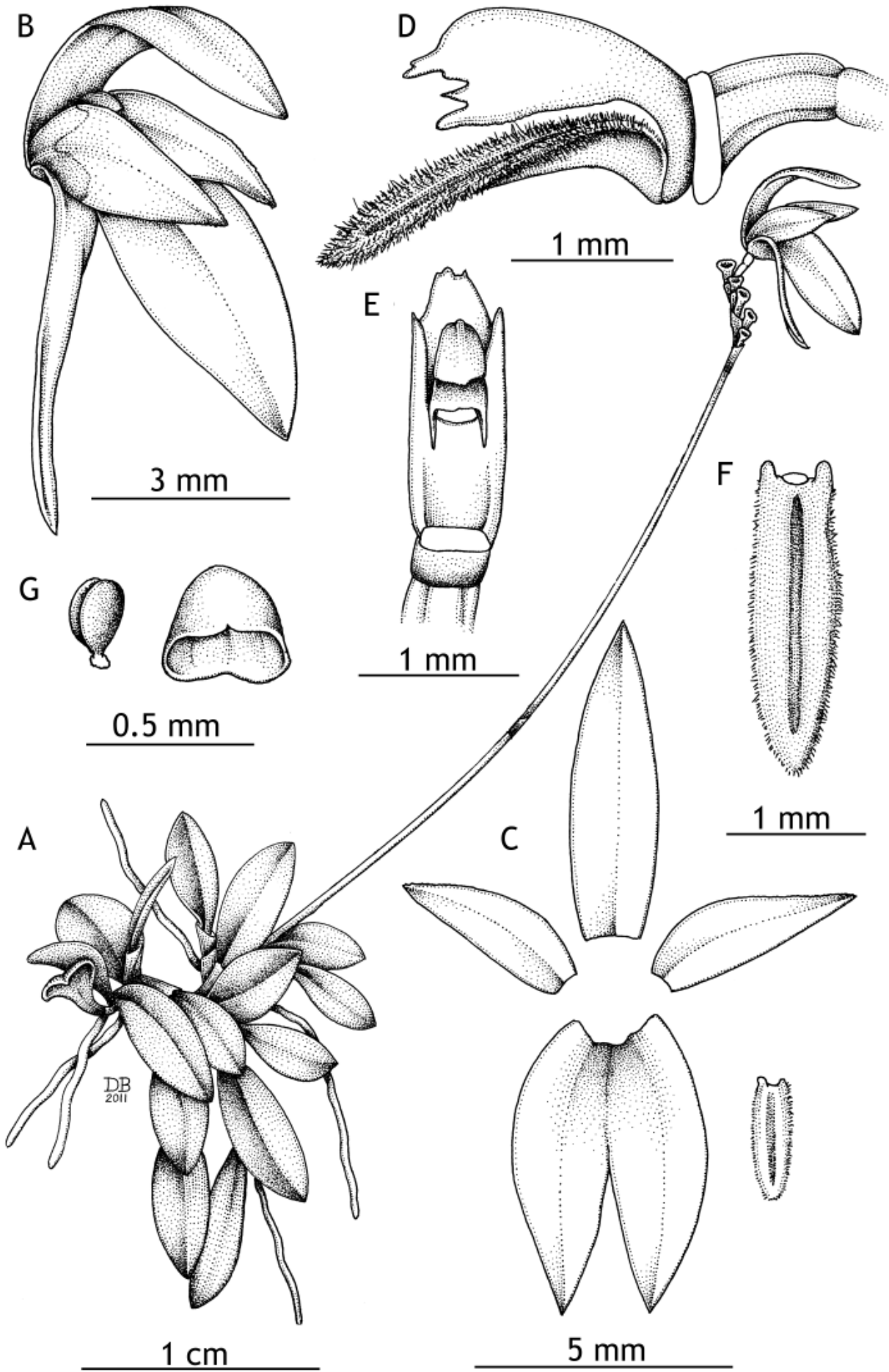

FiguRE 12. Specklinia duplooyi (Luer \& Sayers) Luer. A — Habit. B — Flower. C — Dissected perianth. D — Column and lip, lateral view. E - Column, front view. F - Lip, spread. G - Pollinarium and anther cap. Drawing by D. Bogarín based on Bogarin 7382 (JBL-spirit). 


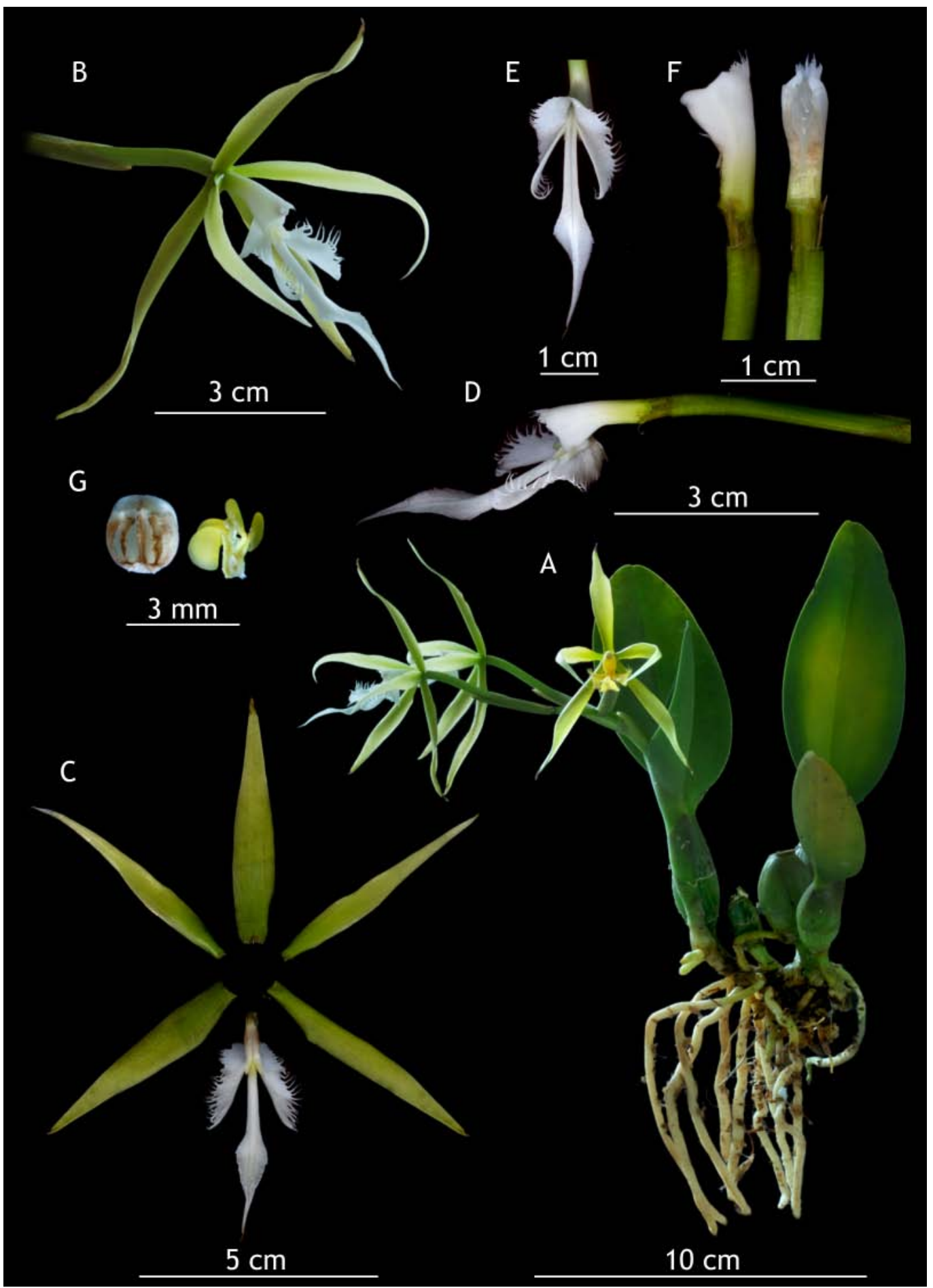

FIGURE 13. Epidendrum $\times$ sandiorum Hágsater, Karremans \& L.Sánchez. A - Habit. B — Flower. C — Dissected perianth. D - Column and lip, lateral view. E - Lip, spread. F — Column, lateral and ventral views. G — Anther cap and pollinarium. Photographs by A.P. Karremans and F. Pupulin based on A.P. Karremans 2781. 

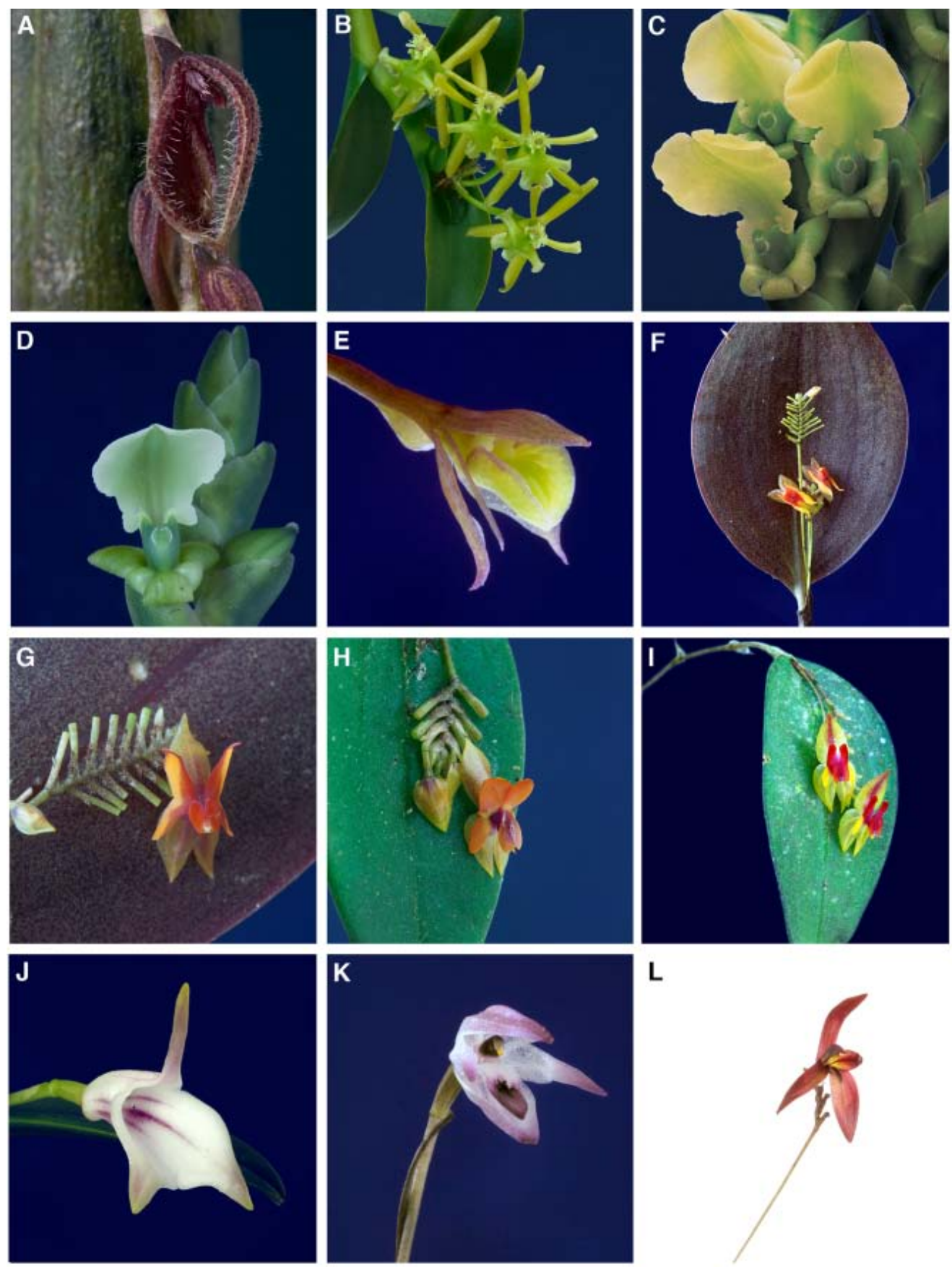

L

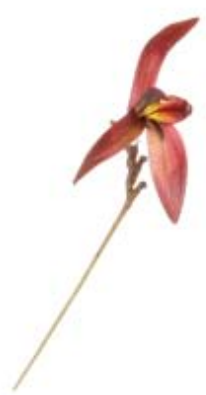

FIgURE 14. A — Acianthera oscitans (Bogarín 7621). B — Epidendrum alieniferum (Karremans 3970). C - Epidendrum circinatum (JBL s.n.). D - Epidendrum concavilabium (Bogarín 4848). E - Epidendrum cystosum (Karremans 3744$).$ F — Lepanthes kabebatae (Bogarin 8873). G — Lepanthes kabebatae (Bogarin 8875). H — Lepanthes psyche (Bogarin 8538). I — Lepanthes regularis (Bogarin 7767). J — Masdevallia nicaraguae (Acosta s.n.). K — Pleurothallis instar (Karremans 2776). L — Specklinia duployii (Bogarín 7382). Photographs by D. Bogarín (F., G., H., I., J. \& L.), A.P. Karremans (B, D, E, K), and F. Pupulin (A, C). 
the prostrate leaves (vs. erect) and the larger flowers with free lateral sepals (vs. smaller, with a synsepal). Also, the petals are sharply acute and microscopically ciliate (vs. acute, ciliate). The lip is narrowly elliptical, long-ciliate, and longitudinally channeled (Luer 2006). The Costa Rican plants were found growing on twigs of abandoned Macadamia trees in exposed condition, an unusual habitat for plants of Specklinia. The morphology of the Costa Rican specimens is consistent with the protologue (Luer 2006).
ACKNOWLEDGEMENTS. We are thankful for the scientific services of Costa Rican Ministry of Environment, Energy and Telecommunications (MINAET) and its National System of Conservation Areas (SINAC) for issuing the Scientific Passports under which wild species treated in this study were collected. Franco Pupulin kindly revised the manuscript and allowed us to use some of his photographs. We thank the Vice-Presidency of Research of the University of Costa Rica for providing support under the projects 814-A7-015 "Inventario y taxonomía de la flora epífita de la región Mesoamericana", 814-BO052, "Flora Costaricensis: Taxonomía y Filogenia de la subtribu Pleurothallidinae (Orchidaceae) en Costa Rica and 814-B1-239 and "Filogenia molecular de las especies de Orchidaceae endémicas de Costa Rica". We are also grateful to the personnel at CR, INB, JBL and USJ for granting full access to their collections.

\section{LiterATURE CITED}

Archila, F. 2000. Estudio taxonómico - morfológico y delimitación de tres géneros de la subtribu Pleurothallidinae (Orchidaceae). Revista Guatemal. 3(1): 33-88.

Archila, F. 2010. Selbyana Archila un nuevo género en la Lycastinae Schltr. Revista Guatemal. 13(1): s.n.

Bainbridge, C. V. \& R. Aguilar. 2008. A new addition to the Costa Rican flora: Palmorchis nitida (Orchidaceae: Neottieae) is documented from the Osa Peninsula. Lankesteriana 8: $1-4$.

Batista, J. A. N., L. B. Bianchetti, R. González-Tamayo, X. M. C. Figueroa \& P. J. Cribb. 2011. A synopsis of New World Habenaria (Orchidaceae) I. Harvard Pap. Bot. 16: 1 - 47 .

Blanco, M. A. 2003. Lepanthes gerardensis (Orchidaceae), a new species from Costa Rica. Lankesteriana 8: 1922.

Blanco, M. A., G. Carnevali Fernández-Concha, D. Bogarín \& R. B. Singer. 2008. Further disentangling of a taxonomic puzzle: Maxillaria ramosa, Ornithidium pendulum, and a new species, O. elianae (Orchidaceae). Harvard Pap. Bot. 13(1): 137-154.

Blanco, M. A., G. Carnevali Fernández-Concha, W. M. Whitten, R. B. Singer, S. Koehler, N. H. Williams, I. Ojeda, K.M. Neubig \& L. Endara. 2007. Generic realignments in Maxillariinae (Orchidaceae). Lankesteriana 7: 515-537.

Blanco, M. A., G. Carnevali Fernández-Concha, W. M. Whitten, R. B. Singer, S. Koehler, N. H. Williams, I.Ojeda, K. M. Neubig \& L. Endara. 2008. Generic realignments in Maxillariinae (Orchidaceae): corrigenda et addenda. Lankesteriana 8: 15.

Bogarín, D. 2007. A new Lycaste (Orchidaceae:
Maxillarieae) from Costa Rica. Lankesteriana 7(3): 543-549.

Bogarín, D. \& M. Fernández, 2010. Lepanthes arenasiana (Pleurothallidinae: Orchidaceae), a new species from Costa Rica. Lankesteriana 9(3): 487-489.

Bogarín, D. \& A. P. Karremans. 2010. Un nuevo Platystele (Orchidaceae: Pleurothallidinae) de la región central de Costa Rica/A new Platystele (Orchidaceae: Pleutothallidinae) from central Costa Rica. Orquideología 27: 208-220.

Bogarín, D., A. P. Karremans \& F. Pupulin. 2008. New records and species of Orchidaceae from Costa Rica. Lankesteriana 8(2): 53-74.

Bogarín, D. \& F. Pupulin. 2010. Two new species of Mormolyca from Costa Rica and Panama. Orchid Digest 74(1): 43-47.

Bogarín, D. \& F. Pupulin. 2011. Lepanthes daniel-jimenezii Bogarín \& Pupulin, spec. nov. (Pleurothallidinae: Orchidaceae), a new species from Costa Rica close to Lepanthes guardiana. Orchidee (Hamburg) 62(2): $111-115$.

Cameron, K. M. 2003. Epistephium. Pages 306-309 in: A. M. Pridgeon, P. J. Cribb, M. W. Chase \& F. N. Rasmussen (eds.). Genera Orchidacearum volume 3: Orchidoideae (Part Two), Vanilloideae. Oxford University Press, Oxford, U.K.

Carnevali Fernández-Concha, G., R. Duno de Stefano, G. A. Romero-González, R. Balam, W. Cetzal Ix, J. L. Tapia-Muñoz \& I. M. Ramírez. 2009. A reappraisal of the turtle-orchids, genus Chelyorchis (Oncidiinae: Orchidaceae): molecular, phylogenetic, and morphometric approaches. J. Torrey Bot. Soc. 136: 164-185. 
Chase, M. W. \& W. M. Whitten. 2011. Further taxonomic transfers in Oncidiinae (Orchidaceae). Phytotaxa 20: $26-32$.

Chase, M. W., N. H. Williams, K. M. Neubig \& W. M. Whitten. 2008. Taxonomic transfers in Oncidiinae to accord with Genera Orchidacearum, Volume 5. Lindleyana 21(3) in Orchids 77: 20-31.

Chiron, G. R. \& V. P. Castro Neto. 2003. Révision du genre Prosthechea Knowles \& Wescott [sic] et nouveau genre dans la tribu Laeliinae (Orchidaceae). Richardiana 4: $9-35$.

Christenson, E. A. 2002. On the identity of Trigonidium seemannii Rchb.f. (Orchidaceae). Kew Bull. 57: 503504.

Christenson, E.A. 2003a. The genus Cischweinfia; a charming group of miniature Oncidium relatives. Orchids 72: $120-129$.

Christenson, E.A. 2003b. Brassia brachiata; a showy Central American species usually confused with Brassia verrucosa. Orchids 72: 296-297.

Christenson, E. A. 2005. Drei neue Stenorrhynchos-Arten/ Three new species of Stenorrhynchos. J. Orchideenfr. 12: $5-25$.

Christenson, E. A. 2006a. Das frühere Phragmipedium caudatum aus Panama/The former Phragmipedium from Panama. J. Orchideenfr. 13: 141-143.

Christenson, E. A. 2006b. Brevilongium, un nouveau genre néotropical (Orchidaceae: Oncidiinae). Richardiana 6: 45-49.

Dressler, R. L. 1993. Field Guide to the Orchids of Costa Rica and Panama. Comstock Publishing Associates, Ithaca, New York.

Dressler, R. L. 2002. The major sections or groups within Sobralia, with four new species from Panama and Costa Rica, S. crispissima, S. gloriana, S. mariannae and $S$. nutans. Lankesteriana 5: 9-15.

Dressler, R. L. 2003. Orchidaceae. Pages $1-595$ in: B.E. Hammel, M.H. Grayum, C. Herrera \& N. Zamora (eds.). Manual de Plantas de Costa Rica, Volumen III: Monocotiledóneas (Orchidaceae-Zingiberaceae). Monogr. Syst. Bot. Missouri Bot. Gard. 93.

Dressler, R. L. 2004a. Der Scaphyglottis pulchella Komplex/ The Scaphyglottis pulchella complex. J. Orchideenfr. 11: $305-315$.

Dressler, R. L. 2004b. Una clave preliminar para las Trichopilia centroamericanas/A preliminary key to the species of Trichopilia in Mesoamerica. Orquideología 23: $35-48$.

Dressler, R. L. 2005. Guarianthe. Pages 251-254 in: A.M. Pridgeon, P.J. Cribb, M.W. Chase \& F.N. Rasmussen (eds.). Genera Orchidacearum, Volume 4: Epidendroideae (Part One). Oxford University Press, Oxford, UK.
Dressler, R. L. 2007. Sobralia macrophylla: y otras Sobralias de brácteas tubulares, con dos especies nuevas, $S$. rarae-avis y $S$. sororcula. Orquideología 25(1): $31-49$.

Dressler, R. L. \& D. Bogarín. 2007. Elleanthus ligularis, a name for a relatively common "new" species of Elleanthus Sect. Chloidelyna. Lankesteriana 7(3): $539-542$.

Dressler, R. L. \& D. Bogarín. 2009. Der Trichopilia tortilis complex (Orchidaceae: Oncidiinae) mit einer schwierig $\mathrm{zu}$ bestimmenden neuen art. The Trichopilia tortilis complex (Orchidaceae: Oncidiinae) with an elusive new species. Orchideen J. 2: 56-65.

Dressler, R. L. \& D. Bogarín, 2010. Some new Sobralieae from Costa Rica and Panama. Lankesteriana 9(3): $475-485$.

Dressler, R. L. \& D. Bogarín. 2011. Sobralia sanctorum and Sobralia purpurella. Orchids (West Palm Beach) 80: $307-310$.

Dressler, R. L. \& S. Dalström. 2004. A synopsis of Cischweinfia (Orchidaceae). Selbyana 25: 1-10.

Dressler, R. L. \& W. E. Higgins. 2003. Guarianthe, a generic name for the "Cattleya" skinneri complex. Lankesteriana 7: 37-38.

Dressler, R. L. \& F. Pupulin. 2005. Some problems in Trichopilia (Orchidaceae: Oncidiinae), with two new species of modest flower size. Harvard Pap. Bot. 10(1): 89-93.

Dressler, R. L. \& F. Pupulin. 2006. The carmine trichopilias of Central America: few but badly confused. Orchids (West Palm Beach) 75: 212-219.

Dressler, R. L. \& F. Pupulin. 2008. La identidad de Sobralia leucoxantha, con tres especies nuevas, dos muy afines y una más lejana. The identity of Sobralia leucoxantha, with three new species, two closely allied and one more distant. Orquideología 25(2): 134-158.

Dressler, R. L. \& F. Pupulin 2011. Phragmipedium Section Phragmipedium. The long-petaled tropical American lady's-slipper orchids. Lindleyana (in Orchids) 80(10): $626-631$.

Dressler, R. L., F. Pupulin \& J. P. Folsom. 2006. Three new Mesoamerican taxa of Dichaea with caducous leaves. Novon 16: 336-343.

Dressler, R. L. \& N. H. Williams. 2000. Chelyorchis. In Romero, G. A. and G. Carnevali Fernández-Concha. Orchids of Venezuela, ed. 2: 1130.

Dressler, R. L. \& N. H. Williams. 2003. New combinations in Mesoamerican Oncidiinae (Orchidaceae). Selbyana 24: $44-45$.

Dudek, M. \& D. L. Szlachetko. 2010. New combinations in subtribe Elleanthinae (Orchidaceae, Epidendroideae). Richardiana 11: 1-12.

Fernández, M. 2011. A reconsideration of Trichosalpinx 
minutipetala (Orchidaceae: Pleurothallidinae). Orquideología 28: 119-134.

Fernández, M. \& D. Bogarín. 2011. A new species of Trichosalpinx (Orchidaceae: Pleurothallidinae) from the northern Pacific lowlands of Costa Rica. Phytotaxa 38: 41-48.

Garay, L.A. 1961. Notes on the genus Epistephium. Amer. Orchid Soc. Bull. 30: 496-500.

Gerlach, G. 2004. Stanhopeinae mesoamericanae II (Orchidaceae). Dos especies nuevas: Polycycnis blancoi y Coryanthes maduroana. Lankesteriana 4: 67-73.

Gerlach, G. \& J. Beeche. 2004. Stanhopeinae mesoamericanae (Orchidaceae). III. Reestablecimiento de Stanhopea ruckeri y una especie nueva: Stanhopea confusa. Lankesteriana 4: 213-221.

Gerlach, G. \& R. L. Dressler. 2003. Stanhopeinae mesoamericanae I. Lankesteriana 8: 23-30.

Gerlach, G. \& A. Romero-González. 2008. Stanhopeinae mesoamericanae IV: las Coryanthes de Charles W. Powell. Lankesteriana 8: 33-42.

Hágsater, E. 1990, Epidendrum parkinsonianum Hook. in E. Hágsater and G. A. Salazar, (eds.) Icon. Orchid. 1: pl. 37.

Hágsater, E. 2003. Epidendrum tolimense Lindl. (Orchidaceae), una especie sudamericana encontrada en Costa Rica. Lankesteriana 8: 41-43.

Hágsater, E. \& L. Sánchez. 1993. Epidendrum lagenocolumna in E. Hágsater and G. A. Salazar, (eds.) Icon. Orchid. 2: pl. 150.

Hágsater, E. \& L. Sánchez (eds.). 2004. The Genus Epidendrum. Part 4. A fourth century of new species in Epidendrum. Icon. Orchid. 7: pl. 701-800.

Hágsater, E. \& L. Sánchez (eds.). 2006. The genus Epidendrum. Part 5. Species new \& old in Epidendrum. Icon. Orchid. 8: pl. 801-900.

Hágsater, E. \& L. Sánchez (eds.). 2007. The genus Epidendrum. Part 6. Species new \& old in Epidendrum. Icon. Orchid. 9: pl. 901-1000.

Hágsater, E. \& L. Sánchez (eds.). 2008. The genus Epidendrum. Part 7. Species new \& old in Epidendrum. Icon. Orchid. 11: pl. 1101-1200.

Hágsater, E. \& L. Sánchez (eds.). 2009. The genus Epidendrum. Part 8. Species new \& old in Epidendrum. Icon. Orchid. 12: pl. 1201-1300.

Hágsater, E. \& M. Soto (eds.). 2003. Orchids of Mexico. Parts 2 \& 3. Icon. Orchid. 5-6: pls. 501-700.

Hágsater, E. \& M. A. Soto. 2005a. Transfers to Epidendrum L. from Oerstedella Rchb. f. Lankesteriana 5: 73-75.

Hágsater, E. \& M. A. Soto. 2005b. Epidendrum. In Pridgeon, A. M., Cribb, P. J., Chase, M. W. and F. N. Rasmussen (eds). Genera Orchidacearum, Volume 4. Epidendroideae (Part One): 236-251. Oxford University Press.

Hamer, F. 2001. Orchidaceae Juss. In: W.D. Stevens, C.
Ulloa, A. Pool \& M. Montiel (eds.). Flora de Nicaragua, Tomo II. Monogr. Syst. Bot. Missouri Bot. Gard. 85: $1612-1860$.

Jenny, R. 2007. An old species finally named and described: Gongora boracayanensis. Selbyana 28: 99-102.

Karremans, A.P. In press. Illustrations and Studies in Neotropical Orchidaceae. 3. On the identity of Dracontia ramonensis (Pleurothallidinae), with a new species. Ann. Naturhist. Mus. Wien. B

Karremans, A.P. \& D. Bogarín. 2011. Pleurothallis adventurae (Orchidaceae: Pleurothallidinae), eine neue art aus einer unerforschten region in Costa Rica. Orchideen J. 18(3): 111-114.

Karremans, A.P. \& E. Hágsater, 2010. Confusion in Epidendrum brenesii Schltr., and a new Costa Rican species: Epidendrum sotoanum (Orchidaceae: Laeliinae). Lankesteriana 9(3): 403-409.

Karremans, A.P. \& M. Muñoz. 2011. Pleurothallis silvaepacis (Orchidaceae: Pleurothallidinae): a new species found at the Bosque de Paz Biological Reserve in Costa Rica. Orchid Rev. 121: 155-159.

Karremans, A. P. \& C. M. Smith. In press. A note on genus Dracontia (Orchidaceae: Pleurothallidinae), with a new species. Harvard Pap. Bot.

Luer, C. A. 1987. New Lepanthes species from Costa Rica and Panama. Lindleyana 2: $185-217$.

Luer, C. A. 2001. Icones Pleurothallidinarum XXI. Systematics of Masdevallia part three. Monographs in Systematic Botany from the Missouri Botanical Garden. 86: 519-780.

Luer, C. A. 2002. Miscellaneous new species in the Pleurothallidinae (Orchidaceae). Selbyana 23: 1-45.

Luer, C. A. 2003. Lepanthes. Pp. 216-255 in: B. E. Hammel, M. H. Grayum, C. Herrera \& N. Zamora (eds.). Manual de plantas de Costa Rica - Volumen III, monocotiledóneas (Orchidaceae-Zingiberaceae). Monogr. Syst. Bot. Missouri Bot. Gard. 93.

Luer, C.A. 2004. Icones Pleurothallidinarum XXVI: Pleurothallis subgenus Acianthera and three allied subgenera; A Second Century of New Species of Stelis of Ecuador; Epibator, Ophidion, Zootrophion. Monogr. Syst. Bot. Missouri Bot. Gard. 95: 1-265.

Luer, C.A. 2005. Icones Pleurothallidinarum XXVII: Dryadella and Acronia sect. Macrophyllae-Fasciculatae (Orchidaceae). Monogr. Syst. Bot. Missouri Bot. Gard. 103: $1-311$.

Luer, C. A. 2006. Icones Pleurothallidinarum XXVIII. Reconsideration of Masdevallia, and the systematics of Specklinia and vegetatively similar genera (Orchidaceae). Monogr. Syst. Bot. Missouri Bot. Gard. 105: $21-244$.

Luer, C. 2007. lcones Pleurothallidinarum XXIX. A third centry of Stelis of Ecuador and Systematics of Apoda- 
Prorepentia and Systematics of Miscellaneous small genera, addenda: new genera, species, and combinations (Orchidaceae). Monogr. Syst. Bot. Missouri Bot. Gard. 112.

Luer, C. 2010. Icones Pleurothallidinarum XXXI: Lepanthes of Bolivia; Systematics of Octomeria Species North and West of Brazil; Addenda and Corrigenda. Monogr. Syst. Bot. Missouri Bot. Gard. Botany 120.

Luer, C. 2011. Miscellaneous new species in the Pleurothallidinae (Orchidaceae) excluding species from Brazil. Harvard Papers in Botany 16(2): 311-360.

Mytnik-Ejsmont, J. 2011. A monograph of the subtribe Polystachyinae Schltr. (Orchidaceae). Uniw. Gdański, Gdańsk, Poland.

Oakeley, H. F. 2008. Lycaste, Ida and Anguloa: the essential guide. The author, Beckenham, Kent, UK.

Ojeda, I., G. Carnevali Fernández-Concha \& G. A. RomeroGonzález. 2005. New species and combinations in Heterotaxis Lindley (Orchidaceae: Maxillariinae). Novon 15: $572-582$.

Ojeda, I., G. Carnevali Fernández-Concha \& G. A. Romero-González. 2009. Nitidobulbon, a new genus of Maxillariinae (Orchidaceae). Novon 19: 96-101.

Ormerod, P. 2002. Taxonomic changes in Goodyerinae (Orchidaceae: Orchidoideae). Lindleyana 17: 189238.

Ormerod, P. 2004. Notulae Goodyerinae. Oasis (Dora Creek) Suppl. 3: 3-19.

Ormerod, P. 2005. Studies of Neotropical Goodyerinae (Orchidaceae). Harvard Pap. Bot. 9: 391-423.

Ormerod, P. 2007. Studies of Neotropical Goodyerinae (Orchidaceae) 2. Harvard Pap. Bot. 11(2): 145-177.

Ormerod, P. 2008. Studies of Neotropical Goodyerinae (Orchidaceae) 3. Harvard Pap. Bot. 13: 55-87.

Ormerod, P. 2009. Studies of Neotropical Goodyerinae (Orchidaceae) 4. Harvard Pap. Bot. 14(2): 111-128.

Pridgeon, A. M. \& M. W. Chase. 2001. A phylogenetic reclassification of Pleurothallidinae (Orchidaceae). Lindleyana 16(4): 235-271.

Pridgeon, A. M. \& M. W. Chase. 2002. Nomenclatural notes on Pleurothallidinae (Orchidaceae). Lindleyana 17: $98-101$.

Pupulin, F. 2002a. Exploring for orchids. Orchids 71: $1016-1019$.

Pupulin, F. 2002b. Catálogo revisado y anotado de las Orchidaceae de Costa Rica. Lankesteriana 4: 1-88.

Pupulin, F. 2003a. Orchideenflora MittelamerikaErgänzungen (Teil 1)/Orchid flora of Central AmericaSupplements (Part 1)/Additamenta ad orchideologiam mesoamericanam (pars 1). Orchidee (Hamburg) 54: $467-477$.

Pupulin, F. 2003b. Orchideenflora MittelamerikaErgänzungen (Teil 2) /Orchid flora of Central America-
Supplements (Part 2)/Additamenta ad orchideologiam mesoamericanam (pars 2). Orchidee (Hamburg) 54: $561-568$.

Pupulin, F. 2003c. Two new species of Stellilabium sect. Taeniorhachis (Orchidaceae: Telipogoninae) from Costa Rica. Harvard Pap. Bot. 8: 29-34.

Pupulin, F. 2004. A note on Prosthechea (Orchidaceae: Laeliinae), with a new species. Selbyana 25(1): 17-22.

Pupulin, F. 2005a. Vanishing beauty: native Costa Rican orchids. Vol. 1. Acianthera-Kegeliella. Editorial Universidad de Costa Rica, San José, Costa Rica. 421 pp.

Pupulin, F. 2005b. Dichaea viridula (Orchidaceae: Zygopetalinae), a new species in the D. tenuifolia complex. Harvard Pap. Bot. 10(1): 83-87.

Pupulin, F. 2005c. Ciliate dichaeas; Dichaea hystricina and Dichaea ciliolata: two species in one and an interesting variation. Orchids (West Palm Beach) 74: 678 - 683 .

Pupulin, F. 2006. Encyclia ossenbachiana (Orchidaceae: Laeliinae), a new species from Costa Rica. Selbyana 27(1): $4-7$.

Pupulin, F. 2007. Contributions toward a reassessment of Costa Rican Zygopetalinae (Orchidaceae). 3. A systematic revision of Dichaea in Costa Rica. Harvard Pap. Bot. 12: 15-153.

Pupulin, F. \& M. A. Blanco. 2002. A new species of Stellilabium section Taeniorhachis (Orchidaceae) from Costa Rica. Lankesteriana 5: 27-30.

Pupulin, F. \& D. Bogarín. 2004. Two new species of Lepanthes (Orchidaceae: Pleurothallidinae) from Costa Rica. Kew Bull. 59: 559-563.

Pupulin, F. \& D. Bogarín. 2005a. The genus Brassia in Costa Rica: a survey of four species and a new species. Lindleyana in Orchids 74(3): 202-207.

Pupulin, F. \& D. Bogarín. 2005b. The genus Scelochilus. Determining the number of species in Central America. Orchids (West Palm Beach) 94(7): 526 - 533.

Pupulin, F. \& D. Bogarín. 2007. A second new species in the genus Restrepiella (Orchidaceae: Pleurothallidinae). Willdenowia 37: 323-329.

Pupulin, F. \& D. Bogarín. 2010a. Illustrations and studies in Neotropical Orchidaceae — The Lepanthes jimenezii group (Pleurothallidinae). Harvard Pap. Bot. 15(1) $111-121$.

Pupulin, F. \& D. Bogarín. 2010b. The genus Campylocentrum (Orchidaceae: Angraecinae) in Costa Rica: a review. Harvard Pap. Bot. 15(2): 353-414.

Pupulin, F. \& D. Bogarín. 2011a. Two new Lepanthes from Costa Rica. Lindleyana in Orchids (West Palm Beach) 80(3): $169-181$.

Pupulin, F. \& D. Bogarín. 2011b. A new, large-flowered species of Lepanthes from Costa Rica. Orchidee (Hamburg) 62(6): 469-477. 
Pupulin, F. \& D. Bogarín. 2012. Lepanthes novae Tapantienses. Orchid Digest. 76(1): 20-29.

Pupulin, F., D. Bogarín \& M. Fernández. 2010a. A note on Pleurothallis luctuosa (Orchidaceae: Pleurothallidinae), with a new species. Ann. Naturhist. Mus. Wien. B, 112: $239-252$.

Pupulin, F., D. Bogarín \& M. Fernández. 2010b. On the identity of Myoxanthus scandens (Orchidaceae: Pleurothallidinae), with a new species. Lankesteriana 9(3): 467-473.

Pupulin, F., D. Bogarín \& D. Jiménez. 2009. New species and records in Mesoamerican Lepanthes. Orchid Digest 73: $136-145$.

Pupulin, F., D. Bogarín \& C. M. Smith. 2010. Two new species of Lepanthes from Costa Rica close to L. schizocardia (Orchidaceae: Pleurothallidinae). Lankesteriana 9(3): 423-430.

Pupulin, F., R. L. Dressler \& H. Medina. 2009. A revision of the white-flowered species of Chondroscaphe (Orchidaceae: Zygopetalinae). Orchid Digest 73: 3251.

Pupulin, F. \& A.P. Karremans. 2010a. Crossoglossa sotoana (Orchidaceae: Malaxideae), a new species honoring the Mexican botanist, Miguel Ángel Soto Arenas. Lankesteriana 9(3): 443-446.

Pupulin, F. \& A.P. Karremans. 2010b. Two new species and a new record of Epidendrum (Orchidaceae: Laeliinae) from Costa Rica. Selbyana 30(2): 195-202.

Pupulin, F., H. Medina \& D. Bogarín. 2010. Two Lepanthes (Orchidaceae: Pleurothallidinae) with a reduced corolla. Orchideen J. 17(3): 117-121.

Pupulin, F. \& G. Merino. 2008. Two new species of Kefersteinia (Orchidaceae: Zygopetalinae). Willdenowia 38: $1-7$.

Pupulin, F. \& G. Rojas. 2006. A new species of Sigmatostalix (Orchidaceae: Oncidiinae) from Costa Rica, and its concolorous form. Lindleyana in Orchids 76: 677683.

Pupulin, F., G. Rojas \& J. D. Zúñiga. 2007. Three new species of Acianthera (Orchidaceae: Pleurothallidinae) from Costa Rica. Harvard Pap. Bot. 12(1): 163-170.

Pupulin, F. \& J. D. Zúñiga. 2007. The upside-down Pleurothallis of Mesoamerica, with a new species from Costa Rica. Lindleyana in Orchids 77: 834-843.

Romero-González, G. A. \& G. Carnevali FernándezConcha. 1999. Notes on the species of Cyrtopodium (Cyrtopodinae, Orchidaceae) from Florida, the Greater Antilles, Mexico, Central America and northern South America. Harvard Pap. Bot. 4: 327-341.

Romero-González, G. A. \& C. H. Dodson. 2010. A la tercera se gana: the validation of Benzingia (Orchidaceae: Zygopetalinae). Lankesteriana 9: 526.

Romowicz, A. \& D. L. Szachetko. 2006. Genera et species orchidalium. 12. Oncidieae. Polish Bot. J. 51: 43-47.

Rutkowski, P., J. Mytnik \& D. L. Szlachetko. 2004. New taxa and new combinations in Mesoamerican Stenorrhynchidinae (Orchidaceae, Spirantheae). Ann. Bot. Fenn. 41: 479—489.

Salazar, G. A. 1990. Cattleya aurantiaca. Icon. Orchid. 1: plate 7.

Sánchez, L. \& Hágsater, E. 2007. Epidendrum firmum Rchb.f. in Hágsater, E. \& L. Sánchez Saldaña (eds.) Icon. Orchid. 9: pl. 937.

Sánchez, L. \& E. Hágsater. 2008a. Epidendrum $\times$ dorotheae P.H.Allen, in Hágsater, E. \& L. Sánchez Saldaña (eds.) Icon. Orchid. 11: pl. 1119.

Sánchez, L. \& E. Hágsater. 2008b. Epidendrum oerstedii Rchb.f. in Hágsater, E. \& L. Sánchez Saldaña (eds.) Icon. Orchid. 11: pl. 1151.

Sánchez, L. \& E. Hágsater. 2010. Epidendrum ciliare L. in Hágsater, E. \& L. Sánchez Saldaña (eds.) Icon. Orchid. 13: pl. 1317.

Santiago, E. \& E. Hágsater. 2010. Epidendrum cystosum Ames in Hágsater, E. \& L. Sánchez Saldaña (eds.) Icon. Orchid. 13: pl. 1325.

Smith, C. M. \& F. Pupulin. In prep. Contributions to a taxonomic revision of Masdevallia (Orchidaceae: Pleurothallidinae) in Costa Rica. A note on Masdevallia attenuata.

Solano, R., G. A. Salazar \& R. Jiménez. 2011. New combinations in Orchidaceae of Mexico. Acta Bot. Mex. 97: 49-56.

Soto Arenas, M. A. \& R. L. Dressler. 2010. A revision of the Mexican and Central American species of Vanilla Plum. ex Mill. with a characterization of their ITS region of the nuclear ribosomal DNA. Lankesteriana 9(3): $285-354$.

Szlachetko, D. L. 2003. Senghasia, eine neue Gattung der Zygopetaleae. J. Orchideenfr. 10: 332-344.

Szlachetko, D. L. 2004a. Matériaux pour la révision des Habenariinae (Orchidaceae, Orchidoideae) - 4. Richardiana 4: 52-65.

Szlachetko, D. L. 2004b. Matériaux pour la révision des Habenariinae (Orchidaceae, Orchidoideae) - 5. Richardiana 4: 103-108.

Szlachetko, D. L. 2006. Genera et species orchidalium. 11. Oncidieae. Polish Bot. J. 51: 39-41.

Szlachetko, D. L. 2007. Notes sur l'alliance Stanhopea (Stanhopeinae, Vandoideae). Richardiana 7: 45- 49.

Szlachetko, D. L. \& M. Kras. 2004. Notes sur le genre Habenella. Richardiana 6: 33-39.

Szlachetko, D. L. \& M. Kulak. 2006. Nouvelles combinaisons dans le genre Zosterophyllanthos Szlachetko \& Margónska (Orchidaceae, Pleurothallidinae). Richardiana 6: 183-195.

Szlachetko, D. L., M. Kulak \& A. Romowicz. 2006. Notes 